\title{
Nitrogen utilization, whole-body urea-nitrogen kinetics, omasal nutrient flow, and production performance in dairy cows fed lactose as a partial replacement for barley starch
}

\section{E. L. De Seram, G. B. Penner, and T. Mutsvangwa*}

Department of Animal and Poultry Science, University of Saskatchewan, 51 Campus Drive, Saskatoon, SK, Canada S7N 5A8

\section{ABSTRACT}

The objective of this study was to determine whether the partial replacement of barley starch with lactose (fed as dried whey permeate; DWP) affects N utilization, whole-body urea kinetics, and production in dairy cows. Eight lactating Holstein cows were used in a replicated $4 \times 4$ Latin square design with 28 -d periods. Four cows in one Latin square were ruminally cannulated and used to determine dietary effects on whole-body urea kinetics and $\mathrm{N}$ utilization. Cows were fed a barley-based diet that contained 3.6\% (dry matter basis) total sugar (TSG; designated control), or diets that contained 6.6, 9.6, or $12.6 \%$ TSG. Dietary TSG content was increased by the replacement of barley grain with DWP $(83 \%$ lactose). Diets were isonitrogenous $(\sim 17.3 \%$ crude protein), and starch contents of the control, 6.6, 9.6, and $12.6 \%$ TSG diets were $24.3,22.2,21.2$, and $19.1 \%$, respectively. Whole-body urea kinetics were measured using 4-d infusions of $\left[{ }^{15} \mathrm{~N}^{15} \mathrm{~N}\right]$-urea with concurrent total collections of feces and urine. Dry matter intake (mean $=26.7 \mathrm{~kg} / \mathrm{d})$, milk yield $($ mean $=34.9 \mathrm{~kg} / \mathrm{d})$, and milk protein and fat contents were unaffected by diet. $\mathrm{Ru}-$ minal ammonia- $\mathrm{N}$ concentration decreased linearly as TSG content increased, whereas ruminal butyrate concentration increased linearly as TSG content increased. Urinary excretion of total $\mathrm{N}$ and urea- $\mathrm{N}$ changed quadratically, whereas urinary excretion of total $\mathrm{N}$ (\% of $\mathrm{N}$ intake) tended to change quadratically as TSG content increased. Fecal N excretion linearly increased as TSG content increased. A quadratic response was observed for total $\mathrm{N}$ excretion as TSG content increased. Milk $\mathrm{N}$ and retained $\mathrm{N}$ were not affected by diet. As TSG content increased, we observed quadratic responses in the omasal flow of fluid-associated and total bacterial nonammonia $\mathrm{N}$, endogenous production of urea- $\mathrm{N}$,

Received November 7, 2018.

Accepted March 15, 2019

*Corresponding author: tim.mutsvan@usask.ca urea- $\mathrm{N}$ recycled to the gastrointestinal tract, and urea$\mathrm{N}$ returned to the ornithine cycle. Dietary TSG content did not affect the anabolic utilization of recycled urea$\mathrm{N}$ or the proportion of recycled urea- $\mathrm{N}$ that was used for bacterial growth. Our results indicate that feeding DWP did not influence dry matter intake, milk yield, or milk composition. Feeding DWP decreased ruminal ammonia- $\mathrm{N}$ concentration, but this did not result in positive responses in milk protein secretion or $\mathrm{N}$ balance. The quadratic response in omasal flow of total bacterial nonammonia $\mathrm{N}$ indicated that including TSG beyond $9.6 \%$ of diet dry matter might depress ruminal microbial protein synthesis.

Key words: barley starch, dried whey permeate, nitrogen utilization, urea recycling

\section{INTRODUCTION}

In dairy cows, milk $\mathrm{N}$ efficiency (i.e., milk $\mathrm{N}$ : $\mathrm{N}$ intake) ranges from 20 to 35\% (Chase et al., 2009); thus, most of the feed $\mathrm{N}$ that a cow consumes is excreted. Enhancing microbial protein synthesis (MPS) in the rumen may improve $\mathrm{N}$ utilization by reducing urinary $\mathrm{N}$ excretion. Dietary carbohydrates that are fermented in the rumen provide most of the energy (ATP) that drives MPS; therefore, ensuring an adequate energy supply in the rumen improves N utilization (NRC, 2001). Starch from cereal grains is the major carbohydrate in dairy diets, and the rate of ruminal starch fermentation is among the important factors that affect MPS (NRC, 2001). Because sugars such as lactose are more rapidly fermented in the rumen than starch $(40-60 \% / h$ vs. 20-40\%/h; Van Amburgh et al., 2015), adding sugars to dairy diets as a partial replacement for starch may increase ruminal ATP supply, thus improving MPS and $\mathrm{N}$ utilization.

Dietary inclusion of sucrose (Broderick et al., 2008; Penner and Oba, 2009) or lactose (DeFrain et al., 2004) as a partial substitution for corn starch improved DMI in dairy cows. Also, milk yield (Broderick and Radloff, 2004) and milk fat yield (Broderick et al., 2008; Penner 
and Oba, 2009) increased when sucrose partially replaced corn starch. However, results of other studies showed that dietary addition of sucrose or lactose in cereal grain-based diets had no effects on production (DeFrain et al., 2006; Penner et al., 2009; Chibisa et al., 2015). Similar to production performance, the effects of partial substitution of cereal grain starch with sugars on ruminal N utilization are inconsistent. Partial substitution of barley starch with dextrose increased ruminal microbial $\mathrm{N}$ outflow in dairy cows fed foragebased diets (Piwonka et al., 1994). However, dietary inclusion of sucrose did not increase MPS in dairy cows fed corn-based diets (Broderick et al., 2008). In fact, Sannes et al. (2002) reported a decrease in MPS when dairy cows were fed sucrose as a partial substitution for corn starch. The type of sugar and its dietary inclusion level could be partly responsible for these inconsistent findings (Oba, 2011). The majority of studies that have explored the effects of partial replacement of dietary starch with sugars on production and $\mathrm{N}$ use have been conducted with corn-based diets, but research with barley-based diets is limited (Khorvash et al., 2014; Chibisa et al., 2015). Recently, Chibisa et al. (2015) reported no effects on DMI and milk production in cows fed diets ( $8 \%$ total sugar) containing dried whey permeate (DWP; a rich source of lactose) as a partial replacement for barley starch compared with those fed a control diet (3\% total sugar). In that study, increasing dietary total sugar content resulted in a decrease in ruminal $\mathrm{NH}_{3}-\mathrm{N}$ concentration, partly suggesting an improvement in ruminal $\mathrm{N}$ use. However, in those studies (Broderick and Radloff, 2004; Broderick et al., 2008) that have reported positive production responses to supplemental sugars, dietary total sugar content was up to $10 \%$, which is greater than the maximum total sugar level of $8 \%$ that was used by Chibisa et al. (2015). Therefore, it is important to determine the responses in production outcomes and $\mathrm{N}$ utilization when cows fed barley-based diets receive dietary total sugar contents $>8 \%$.

Besides providing more fermentable energy for MPS, the substitution of starch with sugars may also improve $\mathrm{N}$ utilization by increasing urea recycling to the rumen because increasing carbohydrate digestion in the rumen increased both urea transfer from blood into the rumen and MPS (Huntington, 1989; Theurer et al., 2002). Lu et al. (2014) demonstrated that ammonia significantly inhibited urea transfer across ruminal epithelia in a dose-dependent manner. Because feeding sugars in place of starch increases ATP supply in the rumen (Russell et al., 1992) and decreases ruminal ammonia concentration (Sannes et al., 2002; Broderick et al., 2008), this could create environmental conditions that are favorable for the trans-epithelial transfer of urea into the rumen. In support of this assertion, replacing starch with sugar decreased urinary excretion of urea in cows (Broderick and Radloff, 2004; Broderick et al., 2008), suggesting a repartitioning of urea toward recycling to the gastrointestinal tract (GIT); however, direct evidence of an increase in urea recycling to the GIT in cows receiving supplemental sugar is scarce. Previously, sucrose supplementation of mostly grass-based diets in sheep (Kennedy et al., 1981) and beef steers (Kennedy, 1980) increased urea transfer to the rumen; however, that research was conducted with slow-growing, nonlactating ruminants fed at low intakes.

Our objective was to delineate the effects of partial replacement of barley starch with DWP (graded levels up to $12.5 \%$ total sugar level) on ruminal fermentation, $\mathrm{N}$ utilization, urea recycling to the GIT, omasal nutrient flow, and production performance in dairy cows. We hypothesized that the partial substitution of barley starch with DWP would improve production performance and $\mathrm{N}$ utilization in dairy cows.

\section{MATERIALS AND METHODS}

The use of cows in this experiment and all procedures that were conducted were approved by the University of Saskatchewan Animal Care Committee (UCACS Protocol No. 20040048). The care and handling of experimental cows followed the guidelines of the Canadian Council on Animal Care (2009).

\section{Animals and Experimental Design}

Eight lactating, multiparous Holstein cows (mean \pm SD: $\mathrm{DIM}=97 \pm 10 ; \mathrm{BW}=733 \pm 47 \mathrm{~kg}$ at the beginning of the study) were used in a replicated $4 \times 4$ Latin square design with 4 dietary treatments. Each period lasted $28 \mathrm{~d}$ and consisted of $18 \mathrm{~d}$ of dietary adaptation and $10 \mathrm{~d}$ of data and sample collection. Four cows in one Latin square were ruminally cannulated and used to determine dietary effects on ruminal fermentation, omasal nutrient flow, whole-body urea kinetics, and $\mathrm{N}$ utilization. All cows were housed in individual tiestalls at the Rayner Dairy Research and Teaching Facility (University of Saskatchewan).

\section{Experimental Treatments and Feeding Management}

Cows were fed a barley silage-based diet that contained 3.64\% (DM basis) total sugar [TSG; designated control), or diets that contained 6.6, 9.6, or $12.6 \%$ TSG. Dietary TSG content was manipulated by the replacement of dry-rolled barley grain with DWP (Saputo Inc., Tulare, CA). According to the manufacturer's specifications, DWP contained $83 \%$ lactose. 
Table 1. Ingredient and chemical composition (\% of DM unless otherwise noted) of experimental diets containing dried whey permeate (as a strategy to increase dietary content of total sugar; TSG) as a partial replacement for barley starch

\begin{tabular}{|c|c|c|c|c|}
\hline \multirow[b]{2}{*}{ Item } & \multicolumn{4}{|c|}{ Experimental diet } \\
\hline & Control & $6.6 \%$ TSG & $9.6 \% \mathrm{TSG}$ & $12.6 \%$ TSG \\
\hline \multicolumn{5}{|l|}{ Ingredient composition } \\
\hline Alfalfa hay & 14.3 & 14.3 & 14.3 & 14.3 \\
\hline Barley silage & 35.3 & 35.3 & 35.3 & 35.3 \\
\hline Barley grain, dry-rolled & 27.9 & 24.1 & 20.2 & 16.4 \\
\hline \multicolumn{5}{|l|}{ Pelleted ingredients ${ }^{1}$} \\
\hline Dried whey permeate & - & 3.8 & 7.6 & 11.5 \\
\hline Soybean hulls & 2.5 & 2.1 & 1.8 & 1.4 \\
\hline Wheat DDGS ${ }^{2}$ & 5.5 & 3.9 & 2.9 & 1.4 \\
\hline Canola meal & 5.0 & 6.8 & 7.1 & 8.2 \\
\hline Corn gluten meal & 2.3 & 2.9 & 3.9 & 5.0 \\
\hline Soybean meal & 3.0 & 2.7 & 2.7 & 2.3 \\
\hline Tallow & 0.6 & 0.6 & 0.6 & 0.6 \\
\hline Dairy premix ${ }^{3}$ & 1.8 & 1.8 & 1.8 & 1.8 \\
\hline Sodium bicarbonate & 1.0 & 1.0 & 1.0 & 1.0 \\
\hline Salt & 0.4 & 0.4 & 0.4 & 0.4 \\
\hline Limestone & 0.2 & 0.2 & 0.2 & 0.2 \\
\hline Dynamate $^{4}$ & 0.2 & 0.2 & 0.2 & 0.2 \\
\hline \multicolumn{5}{|l|}{ Chemical composition } \\
\hline DM, \% & 57.3 & 57.5 & 57.8 & 58.1 \\
\hline $\mathrm{CP}$ & 17.3 & 17.4 & 17.3 & 17.2 \\
\hline $\mathrm{NDF}$ & 34.4 & 34.6 & 33.5 & 32.5 \\
\hline $\mathrm{ADF}$ & 24.6 & 24.9 & 24.1 & 23.1 \\
\hline Starch & 24.3 & 22.2 & 21.2 & 19.1 \\
\hline Total WSC ${ }^{5}$ & 3.6 & 6.6 & 9.6 & 12.6 \\
\hline Ether extract & 2.5 & 2.4 & 2.2 & 2.2 \\
\hline Ash & 9.0 & 10.0 & 9.8 & 11.1 \\
\hline Calcium & 1.0 & 1.2 & 1.2 & 1.5 \\
\hline Phosphorus & 0.6 & 0.6 & 0.6 & 0.6 \\
\hline $\mathrm{NFC}^{6}$ & 36.8 & 35.7 & 37.2 & 37.1 \\
\hline $\mathrm{NSC}^{7}$ & 28.0 & 28.8 & 30.8 & 31.7 \\
\hline $\mathrm{NE}_{\mathrm{L}},{ }^{8} \mathrm{Mcal} / \mathrm{kg}$ of DM & 1.7 & 1.7 & 1.7 & 1.6 \\
\hline
\end{tabular}

${ }^{1}$ Ingredients were pelleted (pellet size: $4 \mathrm{~mm}$ ) and then mixed in the appropriate proportions with dry-rolled barley to prepare the concentrate mixtures.

${ }^{2}$ Dried distillers grains with solubles.

${ }^{3}$ Dairy premix (Masterfeeds LP, Saskatoon, SK, Canada) contained (per kg of premix; DM basis): 250,000 IU of vitamin $\mathrm{A} ; 80,000 \mathrm{IU}$ of vitamin $\mathrm{D}_{3} ; 2,000 \mathrm{IU}$ of vitamin $\mathrm{E} ; 16 \%$, Ca; $6.5 \% \mathrm{P} ; 6.3 \% \mathrm{Na} ; 7.0 \% \mathrm{Mg} ; 2,500 \mathrm{mg}$ of $\mathrm{Zn} ; 1,500 \mathrm{mg}$ of $\mathrm{Mn} ; 675 \mathrm{mg}$ of $\mathrm{Cu} ; 20 \mathrm{mg}$ of Se; $80 \mathrm{mg}$ of I; and $5.52 \%$ ground wheat as the premix carrier. ${ }^{4}$ Dynamate (The Mosaic Company, Plymouth, MN) contained: $18 \% \mathrm{~K} ; 11 \% \mathrm{Mg}$; and $22 \% \mathrm{~S}$.

${ }^{5}$ Water-soluble carbohydrates, which were determined according to Hall (2014) using lactose as a standard.

${ }^{6}$ Calculated as $100-(\% \mathrm{NDF}+\% \mathrm{CP}+\%$ ether extract $+\%$ ash $)$.

${ }^{7}$ Calculated as \%WSC + \%Starch.

${ }^{8}$ Calculated using CPM Dairy Ration Analyzer v3.0.8 (https://cahpwww.vet.upenn.edu/categories/1-CPM).

Diets were formulated to be isonitrogenous $(\sim 17.3 \%$ $\mathrm{CP})$. Because DWP has lower CP content than barley grain (2.8 vs. $11.7 \%$ ), it was necessary to manipulate the dietary inclusion levels of the major protein sources (i.e., wheat dried distillers grains with solubles, canola meal, corn gluten meal, and soybean meal) as incremental amounts of DWP replaced barley grain so as to achieve similar CP contents in experimental diets. The ingredient and chemical compositions of the diets are presented in Table 1. To minimize variations in dietary chemical composition during the course of the experiment, the same batches of concentrate feed ingredients were used to make adequate amounts of all treatment concentrate mixes before the experiment was initiated. Dried whey permeate was included in pellets (see Table 1 for ingredient composition of the experimental pellets), which were then mixed in the appropriate proportions with dry-rolled barley to make the concentrate mixes. Diets were fed as TMR, which were composed of the concentrate mixes plus forage (forage:concentrate ratio of 50:50 on a DM basis). The forage component of the TMR was a mixture of barley silage $(\sim 71 \%$ of forage DM) and chopped alfalfa hay $(\sim 29 \%)$. Cows were fed twice daily at 0830 and $1630 \mathrm{~h}$ for ad libitum intake. 


\section{Data Collection and Sampling}

On d 18 of each experimental period, temporary vinyl catheters $(0.86$ - $\mathrm{mm}$ inside diameter $\times 1.32$-mm outside diameter; Scientific Commodities Inc., Lake Havasu City, AZ) were placed in the right and left jugular veins of the 4 ruminally cannulated cows to facilitate continuous isotope infusion and blood sampling. Wholebody urea- $\mathrm{N}$ kinetics and $\mathrm{N}$ balance were determined from d 19 to 23 as described by Lobley et al. (2000). Briefly, background samples of urine and feces were collected before initiation of isotope infusions on d 19 to measure ${ }^{15} \mathrm{~N}$ natural abundance $\left({ }^{15} \mathrm{NB}\right)$. Jugular infusions of double-labeled urea $\left(\left[{ }^{15} \mathrm{~N}^{15} \mathrm{~N}\right]\right.$-urea, 99.8 atom $\%{ }^{15} \mathrm{~N}$; Cambridge Isotope Laboratories, Andover, MA) prepared in $0.9 \%$ sterile saline were initiated at 1100 $\mathrm{h}$ on d 19 and continued until $0600 \mathrm{~h}$ on d 25. Isotope infusions (1 L per cow/d) were conducted using a peristaltic pump (model 60 RPM/7524-10, Masterflex L/S Microprocessor Pump Drive, Vernon Hills, IL). The daily dosage of $\left[{ }^{15} \mathrm{~N}^{15} \mathrm{~N}\right]$-urea that was infused (range of 0.34 to $0.47 \mathrm{~g}$ per cow $/ \mathrm{d}$ ) was determined based on the mean $\mathrm{N}$ intake of individual cows from d 10 to 15 of the experimental period, such that the predicted plateau enrichment of $\left[{ }^{15} \mathrm{~N}^{15} \mathrm{~N}\right]$-urea in urine was 0.05 atom percent excess (APE). For determination of whole-body urea kinetics and $\mathrm{N}$ balance, total collections of urine and feces were conducted daily from $1100 \mathrm{~h}$ on d 19 to $1100 \mathrm{~h}$ on d 23 (i.e., a total of $4 \mathrm{~d}$ ). Feces were collected into large steel trays that were placed over the gutter behind each tiestall. Total daily fecal output of each cow was thoroughly mixed, quantitatively transferred into a plastic container of known weight, and weighed. A $2.5 \%$ subsample of daily fecal output was collected and stored at $-20^{\circ} \mathrm{C}$ for later chemical analysis. To facilitate urine collection, indwelling Bardex Foley urinary bladder catheters (26 Fr, 75-mL ribbed balloon, lubricious-coated; C. R. Bard Inc., Covington, GA) were inserted at $0900 \mathrm{~h}$ on $\mathrm{d} 18$ as described by Crutchfield (1968). Bladder catheters were connected to urine collection tubing at the initiation of isotope infusion on $d$ 19 at $1100 \mathrm{~h}$. Urine was collected into 20-L preweighed Carboy polyethylene containers. To prevent microbial growth and volatilization of $\mathrm{NH}_{3}-\mathrm{N}$ in urine, $150 \mathrm{~mL}$ of concentrated $\mathrm{HCl}$ was added daily into each empty carboy container such that urinary $\mathrm{pH}$ was maintained below 3. The weight of total daily urine output was recorded and a $5 \%$ subsample that was pooled by cow for each period was collected and stored at $-20^{\circ} \mathrm{C}$ for later $\mathrm{N}$ analysis. A $50-\mathrm{mL}$ subsample of urine was also collected (before pooling) daily and stored at $-20^{\circ} \mathrm{C}$ to determine $\left[{ }^{15} \mathrm{~N}^{14} \mathrm{~N}\right]$ - and $\left[{ }^{15} \mathrm{~N}^{15} \mathrm{~N}\right]$-urea enrichments. In addition, a 2-mL subsample was collected into a 15$\mathrm{mL}$ centrifuge tube containing $8 \mathrm{~mL}$ of double-distilled
$\mathrm{H}_{2} \mathrm{O}$ and stored at $-20^{\circ} \mathrm{C}$ for later analysis of urea- $\mathrm{N}$ concentration.

To quantify omasal nutrient flow, indigestible NDF (iNDF; Huhtanen et al., 1994), ytterbium chloride ( $\mathrm{YbCl}_{3}$; Siddons et al., 1985), and Cr-EDTA (Udén et al., 1980) were used as digesta markers for the large particle (LPP), small particle (SPP), and fluid (FP) phases, respectively. Detailed descriptions of the procedures for quantifying omasal digesta flow can be obtained from Reynal et al. (2005). Briefly, to determine the natural ${ }^{15} \mathrm{~N}$ abundance in omasal digesta, a $500-\mathrm{mL}$ sample of omasal digesta was collected on d 19 before the initiation of ruminal marker infusions. Marker solutions of Cr-EDTA and $\mathrm{YbCl}_{3}$ were prepared in double-distilled $\mathrm{H}_{2} \mathrm{O}$. A priming dose that was equivalent to half of the daily dose of $\mathrm{Cr}$ and $\mathrm{Yb}$ was administered into the rumen via the ruminal cannula on d 19. Subsequently, Cr-EDTA and $\mathrm{YbCl}_{3}$ marker solutions were infused continuously into the rumen for $6 \mathrm{~d}$ (d 19 to 25) using a peristaltic pump (model 205U, Watson and Marlow, Cornwall, UK). Marker solutions were infused at a constant infusion rate of $1 \mathrm{~L}$ per cow/d, which supplied 2.2 $\mathrm{g}$ of $\mathrm{Yb}$ and $2.7 \mathrm{~g}$ of $\mathrm{Cr}$ per day. The weight of marker solution that was infused daily was recorded. Omasal digesta samples were obtained (d 23 to 25 ) using the omasal sampling technique as described by Huhtanen et al. (1997). Omasal digesta samples were collected at 0900,1500 , and $2100 \mathrm{~h}$ on d 23 ; at 0300,1200 , and $1800 \mathrm{~h}$ on $\mathrm{d} 24$; and at 0000 and $0600 \mathrm{~h}$ on $\mathrm{d} 25$, to represent the 24 -h feeding cycle. It is important to note that omasal digesta sampling was conducted when cows were still receiving intra-jugular $\left[{ }^{15} \mathrm{~N}^{15} \mathrm{~N}\right]$-urea infusions because ${ }^{15} \mathrm{~N}$ was used as a bacterial marker to quantify ruminal bacterial protein production. The omasal sampling tube was inserted at each sampling time to ensure that it was correctly positioned and to minimize any potential negative effects on digesta passage and normal digestive functions if the sampling tube was left in place between samplings. At each sampling, a 525$\mathrm{mL}$ sample of omasal digesta was collected from each cow. From this sample, a 300-mL subsample was pooled for each cow in each period to yield a 2.4-L composite sample that was stored at $-20^{\circ} \mathrm{C}$ for later analysis. A subsample of $100 \mathrm{~mL}$ was also pooled by cow and period and kept frozen at $-20^{\circ} \mathrm{C}$ as a spare sample. The remaining $125-\mathrm{mL}$ subsample was transferred into a 250-mL centrifuge bottle and kept on ice. Two 125$\mathrm{mL}$ subsamples from consecutive samplings were then pooled and used to isolate particle-associated (PAB) and fluid-associated (FAB) bacteria using filtration and differential centrifugation as described by Reynal et al. (2005). Both the PAB and FAB pellets that were obtained after each isolation were pooled by cow per period and stored at $-20^{\circ} \mathrm{C}$. 
Ruminal digesta samples were collected at the same time points as for omasal sampling. Approximately 250 $\mathrm{mL}$ of ruminal digesta was collected from the cranialventral, caudal-ventral, central, and cranial-dorsal sacs of the rumen to yield a 1,000-mL composite sample. The composite sample of ruminal digesta was then strained through 4 layers of cheesecloth. Ruminal fluid $\mathrm{pH}$ was then immediately measured using a portable pH meter (Orion Research Inc., Beverly, MA). Two 10$\mathrm{mL}$ subsamples of strained ruminal fluid were collected into $15-\mathrm{mL}$ centrifuge tubes that contained either $25 \%$ (wt/vol) meta-phosphoric acid or $1 \% \mathrm{H}_{2} \mathrm{SO}_{4}$ and stored at $-20^{\circ} \mathrm{C}$ for later analysis of short-chain fatty acids (SCFA) and $\mathrm{NH}_{3}$ concentrations, respectively. Also, at the same time points as for omasal sampling, jugular blood samples were collected via the contralateral jugular catheter into 10-mL Vacutainer tubes containing lithium heparin (Becton Dickinson, Franklin Lakes, $\mathrm{NJ})$. Blood samples were then centrifuged at 1,500 $\times$ $g$ at $4^{\circ} \mathrm{C}$ for 15 min to obtain plasma. Plasma samples were stored at $-20^{\circ} \mathrm{C}$ for later analysis of plasma ureaN (PUN), glucose, and BHB concentrations.

Feed offered and orts were recorded daily over the entire experimental period. From d 19 to 23, TMR and orts samples were collected and stored at $-20^{\circ} \mathrm{C}$ for later analysis. Daily milk yields for all 8 cows were recorded from d 19 to 28 . Milk samples were collected from all 3 milkings at 0430, 1230, and $1900 \mathrm{~h}$ on d 19 to 23 into vials that contained 2-bromo-2-nitropropane1-2-diol as a preservative. Samples were pooled per cow per day proportionally based on milk yield and submitted to the CanWest DHI Laboratory (Edmonton, AB) for CP, fat, lactose, and MUN analysis.

\section{Sample Analysis}

Pooled milk samples were analyzed for fat, CP, lactose, and MUN concentrations using infrared spectroscopy (MilkoScan 605, Foss Electric, Hillerød, Denmark; AOAC, 1990, method 972.16). At the end of each experimental period, TMR, orts, and fecal samples were thawed overnight at room temperature and subsequently analyzed for DM by drying to constant weight in a forced-air oven at $55^{\circ} \mathrm{C}$ (AOAC, 1990; method 930.15). Dried TMR and orts samples were then ground through a 1-mm screen using a Christy-Norris mill (Christy and Norris Ltd., Chelmsford, UK), and fecal samples were ground through a 1-mm screen using a Retsch ZM100 ultra-centrifuge mill (Retsch-Allee 1-5, Haan, Germany). Following grinding, TMR, orts, and fecal samples were pooled per collection period for each cow. Before the pooling of fecal samples, daily individual sub-samples were taken for analysis for ${ }^{15} \mathrm{~N}$ enrichment. Pooled TMR, orts, and fecal samples were submitted to
Cumberland Valley Analytical Services (Hagerstown, MD) for compositional analysis. Samples were analyzed for ash (AOAC International, 2000; method 942.05), CP (AOAC International, 2000; method 990.03), ether extract (AOAC International, 2006; method 2003.05), ADF (AOAC International, 2000; method 973.18), NDF (Van Soest et al., 1991), starch (Hall, 2009), and minerals (AOAC International, 2000; method 985.01). Heat-stable $\alpha$-amylase and sodium sulfite were used for NDF analysis (without correction for ash content). Total water-soluble carbohydrates (WSC) in pooled TMR, orts, and fecal samples were determined using the method described by Hall (2014).

The 2.4-L composite omasal digesta samples were separated into 3 digesta phases (i.e., LPP, SPP, and FP) according to the method described by Reynal et al. (2005). After separation, the LPP, SPP, and FP samples were freeze-dried. The freeze-dried LPP samples were ground through a 1-mm screen using the Retsch ZM100 ultra-centrifuge mill, and the SPP and FP samples were ground using a coffee grinder. Indigestible NDF concentrations in TMR, orts, LPP, and SPP were determined according to the method described by Ahvenjärvi et al. (2000). Briefly, $1.5 \mathrm{~g}$ of LPP, $3.5 \mathrm{~g}$ of SPP, and $3.0 \mathrm{~g}$ of TMR and ort samples were weighed into $5-\times 10-\mathrm{cm}$ nylon mesh bags $(6-\mu \mathrm{m}$ pore size; part no. 03-6/5, Sefar America Inc., Depew, NY). Samples of TMR, orts, and LPP were weighed in duplicate, and SPP samples were weighed in triplicate. Nylon bags were then incubated in 5 ruminally cannulated cows for 12 consecutive days, such that bags with TMR, orts, LPP, and SPP were evenly distributed across all cows. Following incubation, nylon bags were removed from the rumen and immediately soaked in ice-cold water to prevent further microbial degradation. Nylon bags were then rinsed with cold water until the rinse water was clear, and then soaked in water for $30 \mathrm{~min}$. Thereafter, bags were dried at $55^{\circ} \mathrm{C}$ for $48 \mathrm{~h}$ in a forced-air oven and weighed. Dried samples were analyzed for NDF content (Ankom method 6 for A200 and A2001 series; Ankom Technology, Macedon, NY). To measure Cr and $\mathrm{Yb}$ concentrations, approximately $1-\mathrm{g}$ samples of $\mathrm{LPP}, \mathrm{SPP}$, and $\mathrm{FP}$ were combusted at $550^{\circ} \mathrm{C}$ overnight in a muffle furnace (Lindberg/Blue M Box Furnace, Lindberg/Blue M, Asheville, NC). Combusted samples were digested using $1.5 \mathrm{M} \mathrm{HNO}_{3}$ containing $2 \mathrm{~g} / \mathrm{L} \mathrm{KCl}$ (Vicente et al., 2004), before being analyzed for $\mathrm{Cr}$ and $\mathrm{Yb}$ concentrations using atomic absorption spectrophotometry (Perkin Elmer 2300, Perkin-Elmer Corp., Norwalk, CT). The mean $\mathrm{Cr}$ concentration of $\mathrm{FP}$ (mean = $545 \mathrm{mg} / \mathrm{kg}$ ) was 14 and 20 times greater than that of SPP $($ mean $=39.1 \mathrm{mg} / \mathrm{kg})$ and LPP $($ mean $=27.3 \mathrm{mg} /$ $\mathrm{kg}$ ), respectively. Also, the mean $\mathrm{Yb}$ concentration in SPP $(311 \mathrm{mg} / \mathrm{kg})$ was 2.5 and 3 times greater than that 
in LPP $($ mean $=124.4 \mathrm{mg} / \mathrm{kg})$ and $\mathrm{FP}($ mean $=100.8$ $\mathrm{mg} / \mathrm{kg}$ ), respectively. The iNDF concentration of LPP $($ mean $=392.3 \mathrm{mg} / \mathrm{kg}$ ) was 7.2 times greater than that of SPP (mean $=54.6 \mathrm{mg} / \mathrm{kg}$ ). Because the concentrations of $\mathrm{Cr}, \mathrm{Yb}$, and iNDF were distinctly greater in the respective digesta phases that they were intended to trace, marker concentrations were used to reconstitute omasal true digesta (OTD) flowing out of the rumen using the triple-marker method (France and Siddons, 1986). Also, marker concentrations in SPP and LPP were used to reconstitute 2 -g samples of particle phase (PP; Reynal et al., 2005). Reconstituted OTD was analyzed for OM (AOAC, 1990; method 942.05), CP using the macro-Kjeldahl procedure (AOAC, 1990; method 984.13), ADF (Ankom method 5 for A200 and A2001 series), NDF (Ankom method 6 for A200 and A2001 series), total starch using the Megazyme Total Starch Assay Kit (McCleary et al., 1997; Megazyme International Ireland Ltd., Wicklow, Ireland), and WSC (Hall, 2014).

Frozen bacterial pellets (i.e., PAB and FAB) and ${ }^{15} \mathrm{NB}$ samples were freeze-dried and finely ground using a mortar and pestle. Daily individual and background fecal samples, FP, PP, and OTD samples were pulverized using a ball mill. Finely ground bacterial pellets and ${ }^{15} \mathrm{NB}$ samples, and pulverized FP, PP, and OTD samples were prepared for the analysis of ${ }^{15} \mathrm{~N}$ in NAN as described by Reynal et al. (2005). Thereafter, ${ }^{15} \mathrm{~N}$ enrichment in NAN of the samples was determined by combustion to $\mathrm{N}_{2}$ in an elemental analyzer and continuous flow isotope ratio-mass spectrometry (IRMS; Lobley et al., 2000). Also, ${ }^{15} \mathrm{~N}$ enrichment in daily dried fecal subsamples was determined using IRMS (Lobley et al., 2000). To determine $\mathrm{NH}_{3}-\mathrm{N}$ concentration in OTD samples, 0.5-g OTD samples were processed as described by Reynal et al. (2005), followed by the determination of $\mathrm{NH}_{3}-\mathrm{N}$ concentration (Broderick and Kang, 1980). The OM content in bacterial pellets was analyzed by combustion in a muffle furnace at $600^{\circ} \mathrm{C}$.

Pooled frozen urine samples were thawed at room temperature and subsequently analyzed for total $\mathrm{N}$ using the macro-Kjeldahl procedure (AOAC, 1990; method 984.13). For the determination of $\left[{ }^{15} \mathrm{~N}^{15} \mathrm{~N}\right]$ - and $\left[{ }^{14} \mathrm{~N}^{15} \mathrm{~N}\right]$-urea enrichment, background and daily (i.e., the 50-mL subsample that was collected before pooling) urine samples were thawed at room temperature. Approximately $1.5 \mathrm{mg}$ of urea-N was isolated from thawed urine samples using prepacked ion exchange columns (AG 50W-X8 poly-prep columns, $\mathrm{H}^{+}$form, 100-200 mesh; Bio-Rad Laboratories, Richmond, CA) as described by Archibeque et al. (2001). Thereafter, freeze-dried urine samples were analyzed for $\left[{ }^{14} \mathrm{~N}^{15} \mathrm{~N}\right]$ and $\left[{ }^{15} \mathrm{~N}^{15} \mathrm{~N}\right]$-urea enrichment by IRMS (N-15 Analysis Laboratory, University of Illinois, Urbana-Champaign,
IL) as described by Lobley et al. (2000). With this protocol, the assay conditions result in the production of ions with mass/charge $(\mathrm{m} / \mathrm{z})$ values of 28,29 , and 30 , which correspond to $\left[{ }^{14} \mathrm{~N}^{14} \mathrm{~N}\right]-,\left[{ }^{14} \mathrm{~N}^{15} \mathrm{~N}\right]-$, and $\left[{ }^{15} \mathrm{~N}^{15} \mathrm{~N}\right]-$ urea, respectively. To correct for the production of $\left[{ }^{14} \mathrm{~N}^{15} \mathrm{~N}\right]$-urea due to non-mono-molecular reactions, we analyzed standards that were prepared using $\left[{ }^{15} \mathrm{~N}^{15} \mathrm{~N}\right]$ urea $\left(99.8\right.$ atom $\left.\%{ }^{15} \mathrm{~N}\right)$ and $\left[{ }^{14} \mathrm{~N}^{14} \mathrm{~N}\right]$-urea $(0.368$ atom\% ${ }^{15} \mathrm{~N}$ ) (Lobley et al., 2000). This correction was 5 to $6 \%$, which was in the same range as reported by Lobley et al. (2000).

Plasma glucose concentration was determined using the glucose oxidase/peroxidase enzyme (No. P7119; Sigma, St. Louis, MO) and dianisidine dihydrochloride (No. F5803; Sigma) assay. Urea-N concentration in plasma and diluted urine samples was quantified using the assay described by Fawcett and Scott (1960). Concentrations of BHB in deproteinized plasma samples were determined by enzymatic oxidation of BHB to acetoacetate with 3-hydroxybutrate dehydrogenase (H6501; Roche, Mississauga, ON, Canada), and concomitant reduction of NAD to NADH was determined using a plate reader at $340 \mathrm{~nm}$ wavelength.

Ruminal fluid samples that were preserved with either meta-phosphoric acid or $1 \% \mathrm{H}_{2} \mathrm{SO}_{4}$ were thawed overnight at $4^{\circ} \mathrm{C}$. Thawed samples were vortexed and then centrifuged at $12,000 \times \mathrm{g}$ for $10 \mathrm{~min}$ at $4^{\circ} \mathrm{C}$. A 1 -mL subsample of the supernatant was transferred into a micro-centrifuge tube and recentrifuged at 16,000 $\times g$ for 10 min at $4^{\circ} \mathrm{C}$. For ruminal fluid samples that were preserved with $1 \% \mathrm{H}_{2} \mathrm{SO}_{4}$, the resulting supernatant was analyzed for $\mathrm{NH}_{3}-\mathrm{N}$ concentration using the phenol hypochlorite assay as described by Broderick and Kang (1980). For ruminal fluid samples that were preserved with meta-phosphoric acid, SCFA were separated and quantified using gas chromatography (Agilent 6890 Series GC System, Agilent Technologies, Waldbronn, Germany) as described by Khorasani et al. (1996).

\section{Calculations and Statistical Analysis}

For calculation of total-tract nutrient digestibility, daily nutrient intakes $(\mathrm{kg} / \mathrm{d})$ were determined as follows:

$$
\begin{aligned}
& {[\mathrm{DM} \text { offered }(\mathrm{kg} / \mathrm{d}) \times \% \text { of nutrient in TMR }]} \\
& -[\mathrm{DM} \text { refused }(\mathrm{kg} / \mathrm{d}) \times \% \text { of nutrient in orts }] .
\end{aligned}
$$

For this calculation, DMI of cannulated cows during total collection (i.e., DMI from d 19 to 23 of the experimental period) were used. Apparent total-tract nutrient digestibility was then calculated as 
$\{$ nutrient intake $(\mathrm{kg} / \mathrm{d})$ - fecal nutrient output

$$
(\mathrm{kg} / \mathrm{d})] / \text { nutrient intake }\} \times 100 \text {. }
$$

Omasal flow of nutrients, and apparent and true nutrient digestibilities in the rumen were calculated as described by Reynal and Broderick (2005), as follows:

$$
\mathrm{NAN} \text { in OTD }=\text { total } \mathrm{N}-\mathrm{NH}_{3}-\mathrm{N} .
$$

Total NAN flow at the omasal canal was assumed to contain NAN in FAB, NAN in PAB and, NAN of nonbacterial origin (NANBN) as described by Reynal and Broderick (2005). The ${ }^{15} \mathrm{~N}$ enrichment (APE) in FAB, $\mathrm{PAB}$, and omasal fractions were calculated as

$$
\begin{aligned}
& { }^{15} \mathrm{~N} \text { atom\% in the sample - mean background }{ }^{15} \mathrm{~N} \\
& \text { atom\% (which was } 0.3681 \text { ). }
\end{aligned}
$$

Omasal flows (expressed as $\mathrm{g} / \mathrm{d}$ or $\mathrm{kg} / \mathrm{d}$ ) of FAB NAN, PAB NAN, total bacterial NAN, NANBN, RDP supply, bacterial $\mathrm{OM}$, and $\mathrm{OM}$ truly digested in the rumen (OMTDR) were calculated as described by Reynal et al. (2005), as follows:

$$
\begin{aligned}
& \text { FAB NAN flow }=\text { FP NAN flow } \\
& \times\left(\mathrm{FP}^{15} \mathrm{~N} \text { APE } / \mathrm{FAB}^{15} \mathrm{~N} \text { APE }\right) ; \\
& \text { PAB NAN flow }=\text { PP NAN flow } \\
& \times\left(\mathrm{PP}^{15} \mathrm{~N} \text { APE } / \mathrm{PAB}{ }^{15} \mathrm{~N} \text { APE }\right) ;
\end{aligned}
$$

Total bacterial NAN flow $=$ FAB NAN flow

$$
+ \text { PAB NAN flow; }
$$

NANBN flow $=$ total NAN flow

- total bacterial NAN flow;

$$
\begin{gathered}
\text { RDP supply }=\text { total CP intake } \\
-(\text { NANBN flow } \times 6.25)
\end{gathered}
$$

FAB DM flow =

FAB NAN flow (g/d)/FAB NAN (\%);

PAB DM flow $=$

PAB NAN flow (g/d)/PAB NAN (\%);

FAB OM flow $=$

FAB DM flow $(\mathrm{g} / \mathrm{d}) \times$ FAB OM $(\%)$;
PAB OM flow $=$ PAB DM flow $(\mathrm{g} / \mathrm{d})$

$\times \operatorname{PAB~OM}(\%)$; and

$$
\begin{gathered}
\text { OMTDR }=\text { OM intake } \\
-(\text { omasal OM flow }- \text { total bacterial OM flow }) .
\end{gathered}
$$

The omasal flow of bacterial NAN derived from recycled urea-N (Wickersham et al., 2009) was calculated as

$$
\begin{gathered}
\text { bacterial NAN flow } \\
\times\left(\text { bacterial }{ }^{15} \mathrm{~N} \text { APE/urinary }{ }^{15} \mathrm{~N} \text { APE }\right) .
\end{gathered}
$$

Whole-body urea- $\mathrm{N}$ kinetics were calculated according to the model described by Lobley et al. (2000), using enrichments of $\left[{ }^{14} \mathrm{~N}^{15} \mathrm{~N}\right]$ - and $\left[{ }^{15} \mathrm{~N}^{15} \mathrm{~N}\right]$-urea in urine and ${ }^{15} \mathrm{~N}$ in feces. Across diets, urinary $\left[{ }^{14} \mathrm{~N}^{15} \mathrm{~N}\right]$ - and $\left[{ }^{15} \mathrm{~N}^{15} \mathrm{~N}\right]$-urea enrichments reached a plateau within 24 to $48 \mathrm{~h}$ of isotopic infusion (Figures $1 \mathrm{~A}$ and $1 \mathrm{~B}$ ). This time course in the urinary enrichments of $\left[{ }^{14} \mathrm{~N}^{15} \mathrm{~N}\right]$ - and $\left[{ }^{15} \mathrm{~N}^{15} \mathrm{~N}\right]$-urea is consistent with previous findings (Lobley et al., 2000). However, although ${ }^{15} \mathrm{~N}$ enrichment in feces increased daily over the 4-d isotopic infusion, it did not attain a definite plateau (Figure 2) as reported by Lobley et al. (2000). Therefore, for calculations of whole-body urea kinetics, mean urinary $\left[{ }^{14} \mathrm{~N}^{15} \mathrm{~N}\right]$ - and $\left.{ }^{15} \mathrm{~N}^{15} \mathrm{~N}\right]$-urea enrichments over the final 48 to $96 \mathrm{~h}$ of infusion were used, whereas fecal ${ }^{15} \mathrm{~N}$ enrichments over the final 72 to $96 \mathrm{~h}$ were used. The model calculates (1) endogenous urea-N production (also referred to as urea$\mathrm{N}$ entry rate, UER); (2) the proportion of UER that is lost in the urine (urinary urea-N elimination, UUE); (3) the proportion of UER that is recycled to the GIT (GIT entry rate, GER); (4) the proportion of GER that is excreted as $\mathrm{N}$ products in the feces (urea-N to fecal excretion, UFE); (5) the proportion of GER that re-enters the ornithine cycle (return to ornithine cycle, ROC); and urea-N that is used for anabolic purposes (UUA), which is calculated as GER - (UFE + ROC) (Lobley et al., 2000).

For ruminal fluid and plasma samples that were obtained at different time points during each experimental period, mean values for ruminal fermentation characteristics (i.e., $\mathrm{pH}$, and ammonia- $\mathrm{N}$ and SCFA concentrations) and blood metabolites (i.e., urea-N, glucose, and BHB concentrations) were calculated for each cow per experimental period and then used in statistical analysis. Production data from all 8 cows were analyzed by Proc Mixed of SAS (version 9.4; SAS Institute Inc., Cary, NC) as a replicated $4 \times 4$ Latin square design using the following model: $Y_{i j k l}=\mu+$ $S_{i}+P_{j}+C_{k(i)}+T_{l}+S T_{i l}+E_{i j k l}$, where $Y_{i j k l}$ is the 
dependent variable, $\mu$ is the overall mean, $S_{i}$ is the fixed effect of $i$ th square, $P_{j}$ is the fixed effect of $j$ th period, $C_{k(i)}$ is the random effect of $k$ th cow (within square i), $T_{l}$ is the fixed effect of $l$ th dietary treatment, $S T_{i l}$ is the interaction between ith square and lth dietary treatment, and $E_{i j k l}$ is the residual error. All data on ruminal fermentation characteristics (i.e., $\mathrm{pH}$, and
$\mathrm{NH}_{3}-\mathrm{N}$ and SCFA concentrations), apparent ruminal and total-tract nutrient digestibilities, omasal nutrient and bacterial NAN flows, $\mathrm{N}$ balance, whole-body urea$\mathrm{N}$ kinetics, and blood parameters were analyzed using the Proc Mixed procedure of SAS as a $4 \times 4$ Latin square design according to the following model: $Y_{j k l}=$ $\mu+P_{j}+C_{k}+T_{l}+E_{j k l}$, where $Y_{j k l}$ is the dependent

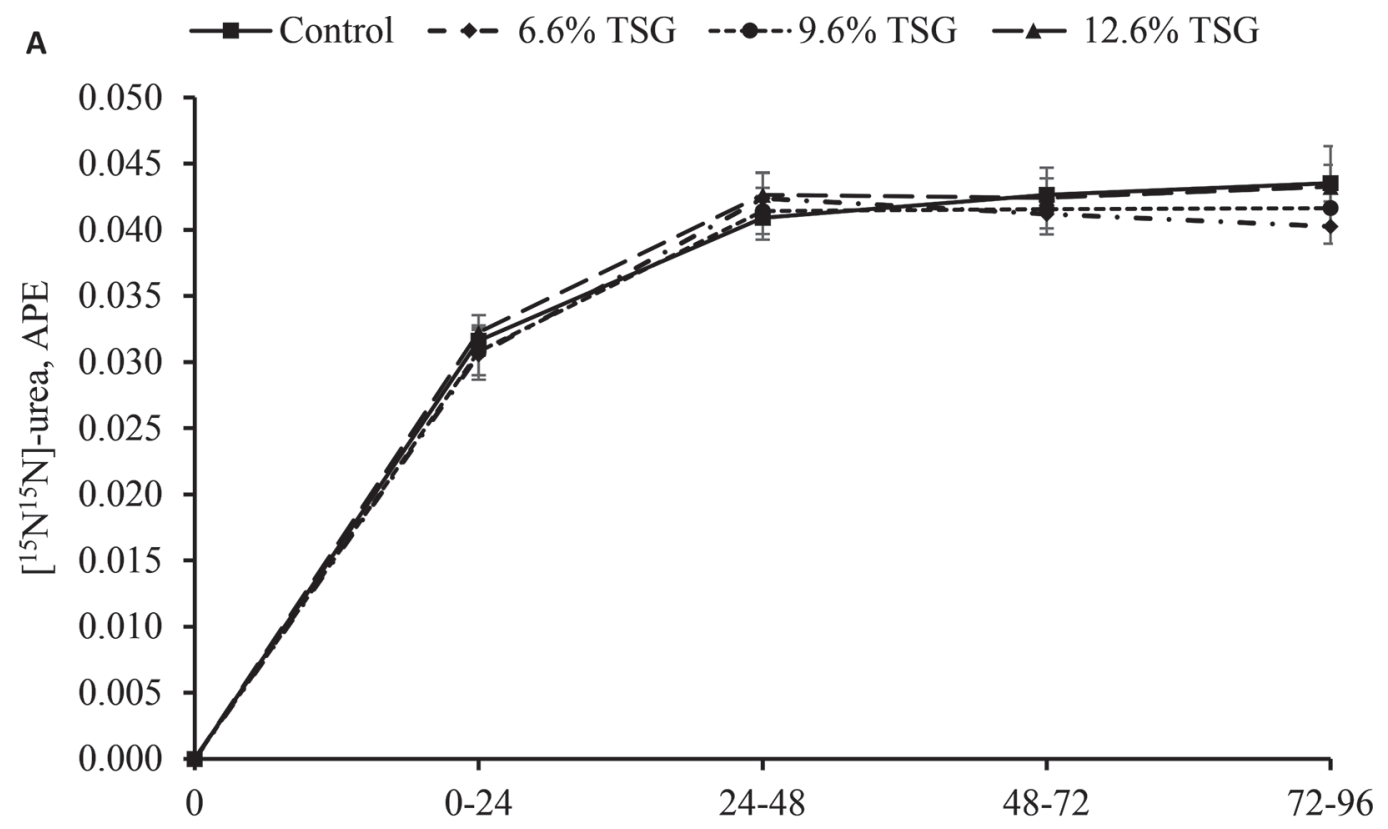

B

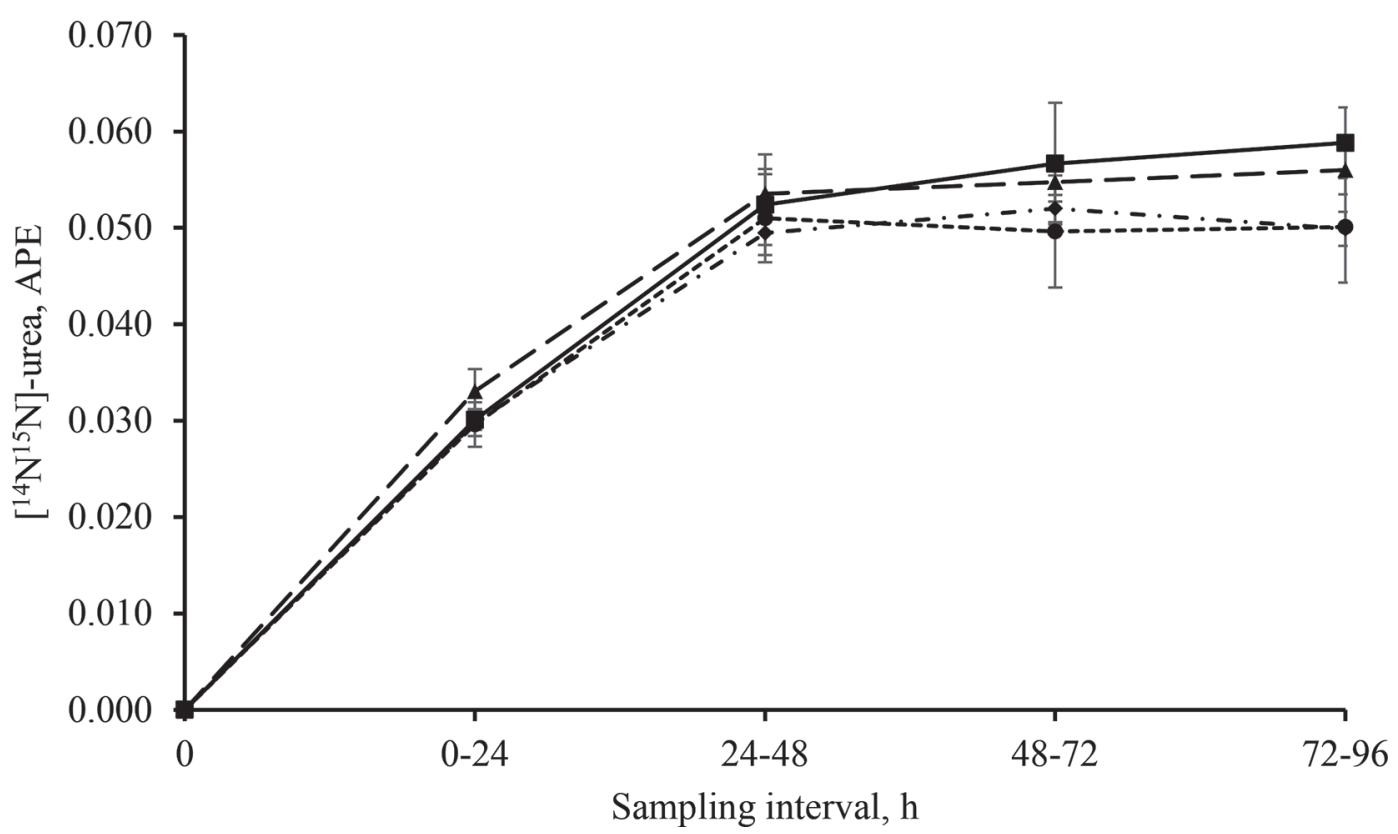

Figure 1. Enrichment (atom percent excess; APE) of $\left[{ }^{15} \mathrm{~N}^{15} \mathrm{~N}\right]$-urea (A) and $\left[{ }^{14} \mathrm{~N}^{15} \mathrm{~N}\right]$-urea (B) in urine during 4-d (d 19 to 23 ) intra-jugular infusions of $\left[{ }^{15} \mathrm{~N}^{15} \mathrm{~N}\right]$-urea in dairy cows fed increasing dietary contents of total sugar (TSG) by the partial replacement of barley starch with dried whey permeate (DWP). Infusions were initiated at $1100 \mathrm{~h}$ on d 19, which is represented by the sampling time $0 \mathrm{~h}$. Dietary treatments were control (no added DWP), 6.6\%, 9.6\%, and 12.6\% TSG. Each data point represents mean enrichment \pm SEM for 4 cows fed experimental diets. 


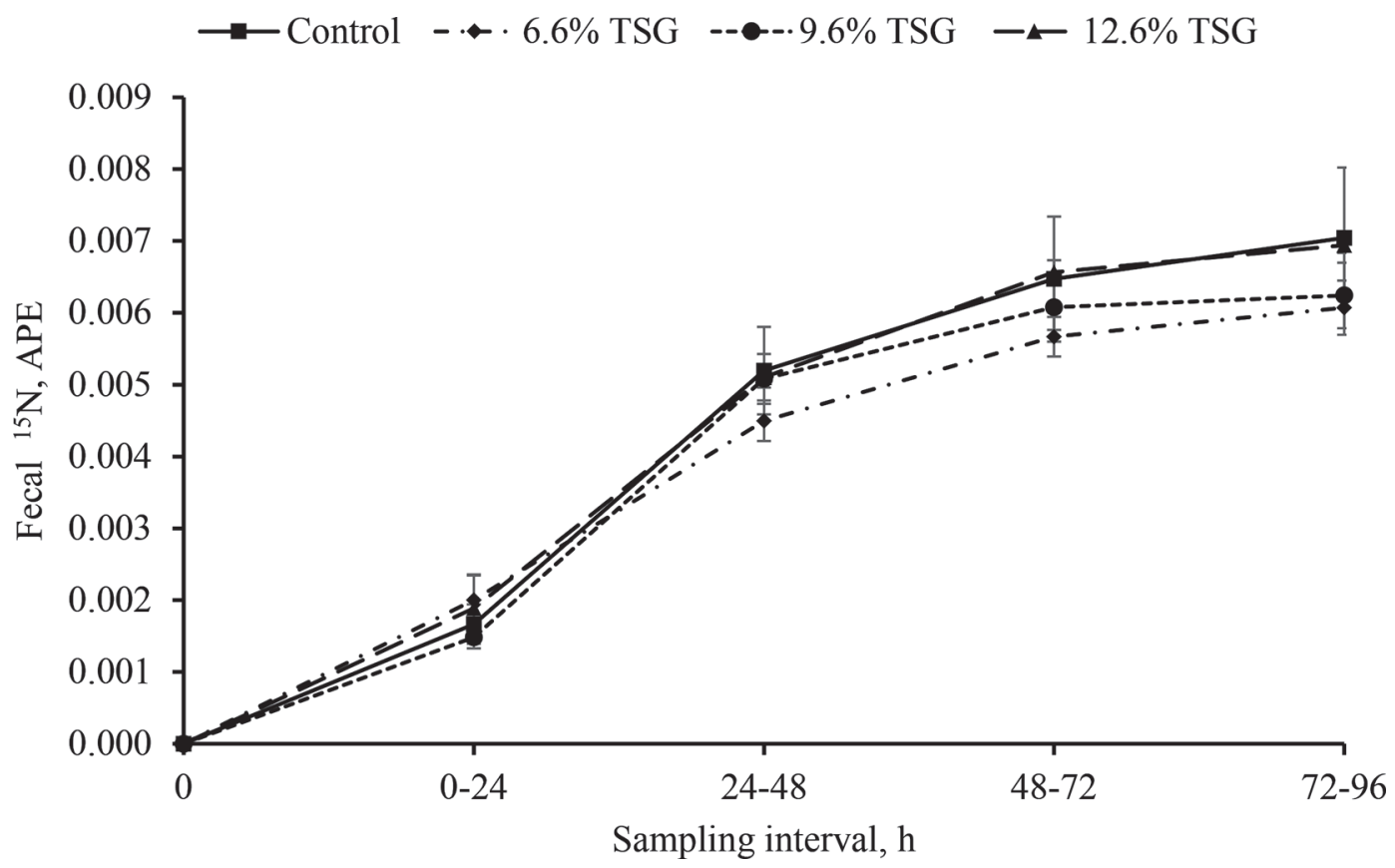

Figure 2. The enrichment (atom percent excess; APE) of fecal ${ }^{15} \mathrm{~N}$ during 4-d (d 19 to 23 ) intra-jugular infusions of $\left[{ }^{15} \mathrm{~N}^{15} \mathrm{~N}\right]$-urea in dairy cows fed increasing dietary contents of total sugar (TSG) by the partial replacement of barley starch with dried whey permeate (DWP). Infusions were initiated at $1100 \mathrm{~h}$ on d 19, which is represented by the sampling interval $0 \mathrm{~h}$. Dietary treatments were control (no added DWP), $6.6 \%, 9.6 \%$, and $12.6 \%$ TSG. Each data point represents mean enrichment \pm SEM for 4 cows fed experimental diets.

variable, $\mu$ is the overall mean, $P_{j}$ is the fixed effect of the $j$ th period, $C_{k}$ is the random effect of the $k$ th cow, $T_{l}$ is the fixed effect of the $l$ th treatment, and $E_{j k l}$ is the residual error. The Kenward-Roger method was used to approximate degrees of freedom. Polynomial contrasts were used to test for linear and quadratic effects of dietary sugar levels. Significance was declared when $P$ $\leq 0.05$, and tendencies were discussed when $0.05<P \leq$ 0.10 . All reported values are least squares means.

\section{RESULTS}

\section{Dietary Characteristics}

The dietary inclusion levels of $0,3.8,7.6$, and $11.5 \%$ of DWP targeted TSG contents of 3.5, 6.5, 9.5, and $12.5 \%$ in experimental diets, respectively. The actual dietary TSG contents based on chemical analysis of diets were $3.6,6.6,9.6$, and $12.6 \%$, respectively (Table 1 ), indicating that we met our target TSG levels. As expected, the partial replacement of barley grain with DWP reduced dietary starch content from 24.3 to 19.1\%. Total NSC and NFC contents ranged from 28.0 to $31.7 \%$ and from 35.7 to $37.2 \%$, respectively, across diets. Dietary CP contents ranged from 17.2 to $17.4 \%$, indicating that our desire to formulate isonitrogenous diets was largely achieved.

\section{Production Parameters and Blood Metabolites}

Dry matter intake, actual and energy-corrected milk yields, and feed efficiency were not affected $(P>0.05)$ by dietary inclusion of DWP as a partial replacement for barley starch (Table 2). Milk fat and protein contents and yields were also not different $(P>0.05)$ among diets. Milk lactose content responded in a quadratic manner when dietary TSG content was increased $(P=$ $0.04)$; however, milk lactose yield was unaffected $(P=$ $0.36)$ by dietary addition of DWP. Dietary inclusion of DWP did not affect MUN $(P=0.12)$, PUN $(P=0.40)$, or BHB $(P=0.17)$ concentrations; however, plasma glucose concentration tended to be affected by diet $(P$ $=0.06$ ) although linear or quadratic trends were not significant.

\section{Ruminal Fermentation Characteristics}

Ruminal concentrations of acetate, propionate, isobutyrate, total SCFA, and total branched-chain fatty acids, and acetate:propionate ratio were not affected $(P>0.05)$ by the dietary inclusion of DWP (Table 3); however, ruminal concentrations of butyrate increased linearly $(P=0.04)$ as dietary TSG content increased. Ruminal concentrations of valerate tended to increase linearly $(P=0.09)$, whereas ruminal concentrations of 
Table 2. The effects of increasing dietary content of total sugar (TSG) by the partial replacement of barley starch with dried whey permeate on DMI, milk yield, and milk composition $(\mathrm{n}=8)$, and blood metabolites $(\mathrm{n}=4)$ in dairy cows

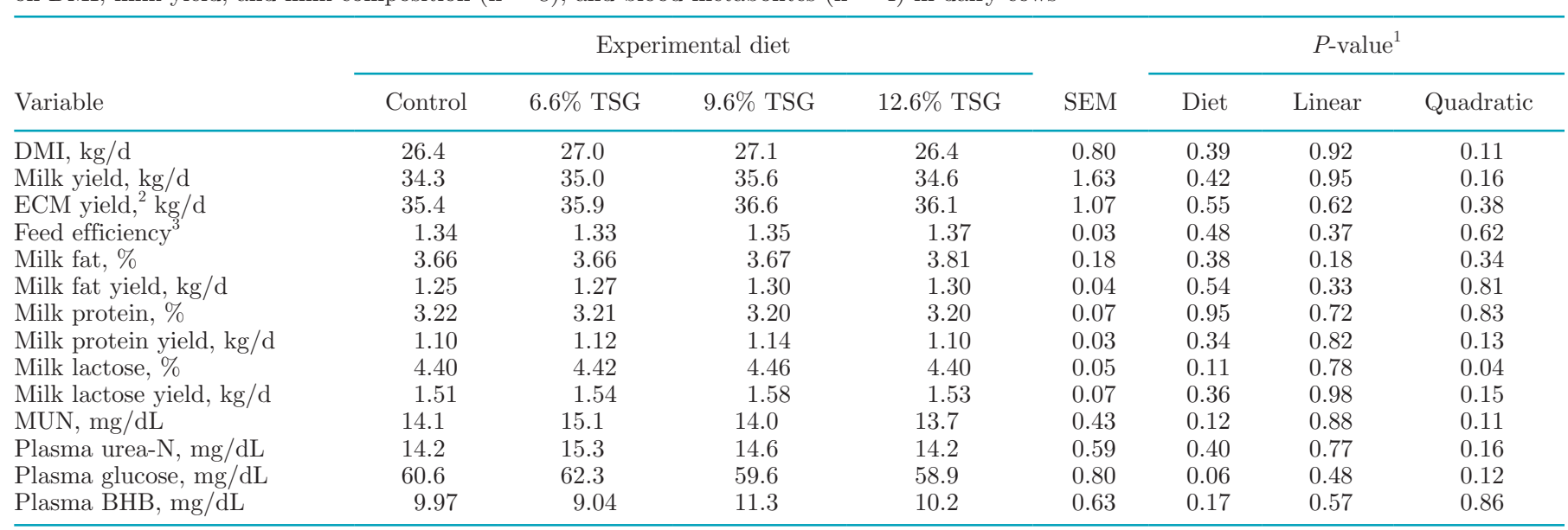

${ }^{1} P$-values indicate overall diet, linear, and quadratic effects.

${ }^{2}$ Calculated as $[0.327 \times$ milk yield $(\mathrm{kg})]+[12.95 \times$ fat yield $(\mathrm{kg})]+[7.2 \times$ protein yield $(\mathrm{kg})]$ (Slater et al., 2000).

${ }^{3}$ Feed efficiency $=$ ECM yield/DMI.

isovalerate tended to decrease linearly $(P=0.10)$ as dietary TSG content increased. Ruminal concentrations of $\mathrm{NH}_{3}-\mathrm{N}$ decreased linearly $(P=0.03)$ as dietary TSG content increased. There was a tendency $(P=0.10)$ for a quadratic response in ruminal $\mathrm{pH}$ as the dietary inclusion of DWP increased.

\section{Nutrient Intakes, Ruminal Digestibilities, and Omasal Nutrient Flows}

For the 4 ruminally cannulated cows that were used in the metabolism experiment, dietary inclusion of DWP did not affect DMI $(P=0.49)$ or OM intake $(P=0.30)$; however, omasal flow of DM tended to decrease linearly $(P=0.07)$, whereas that of $\mathrm{OM}$ decreased linearly $(P=0.04)$ as dietary TSG content increased (Table 4). Apparent ruminal DM digestion, when expressed as kilograms per day $(P=0.02)$ or as a percentage of DMI $(P=0.02)$, increased linearly as dietary TSG content increased. Apparent ruminal OM digestion tended to increase linearly when expressed as kilograms per day $(P=0.06)$ or increased linearly when expressed as a proportion of $\mathrm{OM}$ intake $(P=0.03)$ as dietary TSG content increased. When expressed as kilograms per day or as a proportion of intake, ruminal digestion of $\mathrm{ADF}$ and NDF were not affected by the partial substitution of barley starch with DWP $(P \geq$ 0.59). As expected, starch intake decreased linearly $(P$

Table 3. The effects of increasing dietary content of total sugar (TSG) by the partial replacement of barley starch with dried whey permeate on ruminal fermentation characteristic in dairy cows $(n=4)$

\begin{tabular}{|c|c|c|c|c|c|c|c|c|}
\hline \multirow[b]{2}{*}{ Variable } & \multicolumn{4}{|c|}{ Experimental diet } & \multirow[b]{2}{*}{ SEM } & \multicolumn{3}{|c|}{$P$-value ${ }^{1}$} \\
\hline & Control & $6.6 \% \mathrm{TSG}$ & $9.6 \% \mathrm{TSG}$ & $12.6 \% \mathrm{TSG}$ & & Diet & Linear & Quadratic \\
\hline Acetate & 74.5 & 73.5 & 75.5 & 72.0 & 1.73 & 0.52 & 0.24 & 0.46 \\
\hline Propionate & 23.4 & 22.6 & 24.1 & 22.8 & 1.05 & 0.77 & 0.52 & 0.82 \\
\hline Butyrate & 12.8 & 13.0 & 14.1 & 14.9 & 0.43 & 0.05 & 0.04 & 0.51 \\
\hline Isobutyrate & 0.90 & 0.89 & 0.85 & 0.82 & 0.04 & 0.58 & 0.35 & 0.96 \\
\hline Total SCFA, mmol/L & 115 & 114 & 117 & 113 & 2.81 & 0.84 & 0.60 & 0.67 \\
\hline Total BCFA, mmol/ $\mathrm{L}^{3}$ & 2.38 & 2.32 & 2.20 & 2.10 & 0.09 & 0.26 & 0.14 & 0.81 \\
\hline Acetate:propionate ratio & 3.14 & 3.22 & 3.17 & 3.25 & 0.14 & 0.96 & 0.61 & 0.99 \\
\hline Ruminal ammonia-N, mg/dL & 12.1 & 12.3 & 10.9 & 9.40 & 0.57 & 0.03 & 0.03 & 0.15 \\
\hline Ruminal pH & 6.32 & 6.31 & 6.34 & 6.22 & 0.05 & 0.10 & 0.06 & 0.10 \\
\hline
\end{tabular}

${ }^{1} P$-values indicate overall diet, linear, and quadratic effects.

${ }^{2}$ Short-chain fatty acids.

${ }^{3}$ Branched-chain fatty acids. 
Table 4. The effects of increasing dietary content of total sugar (TSG) by the partial replacement of barley starch with dried whey permeate on ruminal nutrient digestibility and omasal flows of nutrients in dairy cows $(n=4)$

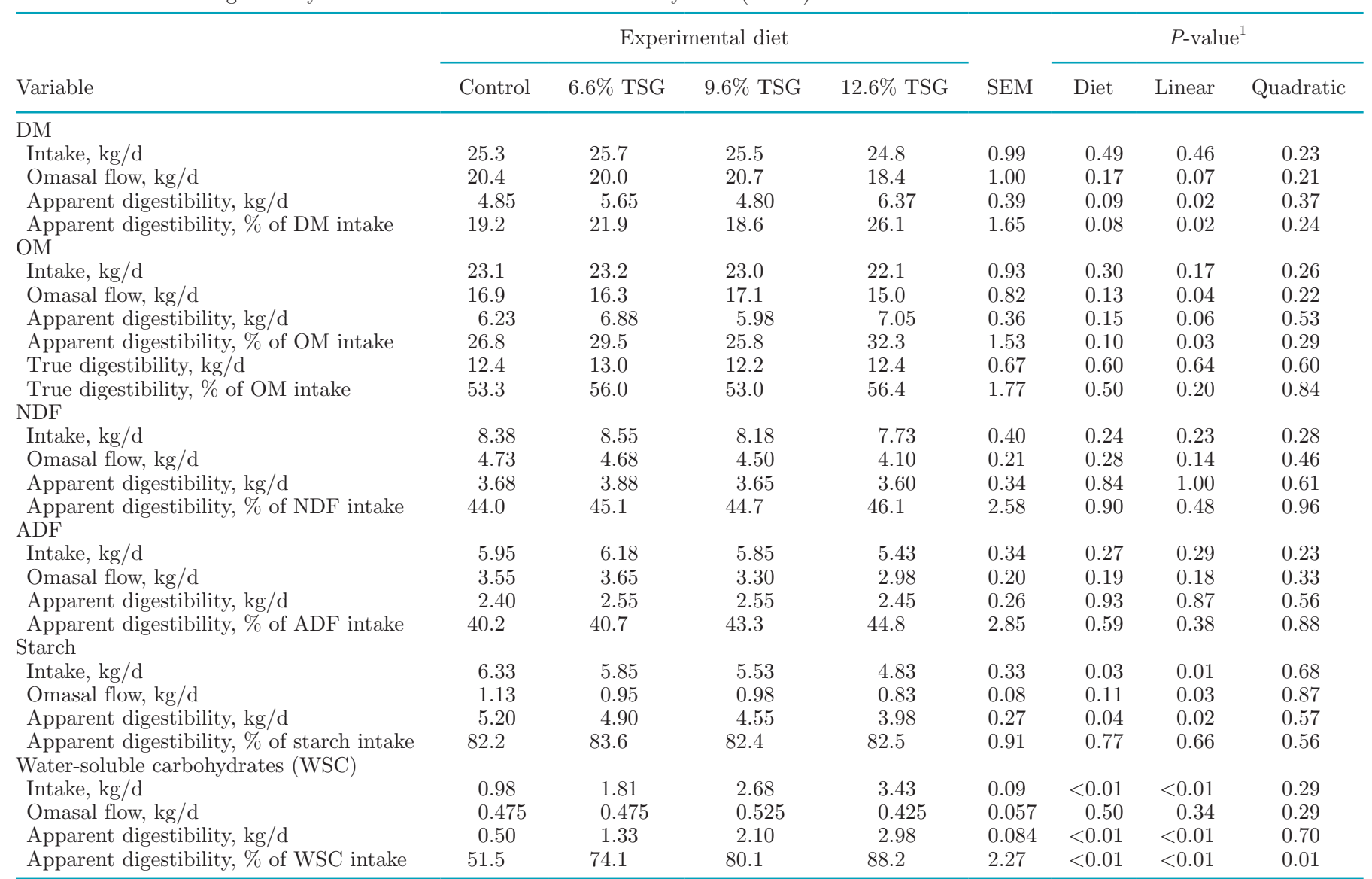

${ }^{1} P$-values indicate overall diet, linear, and quadratic effects.

$=0.01)$ when dietary content of DWP increased. Both the flow of starch at the omasal canal $(P=0.03)$ and apparent ruminal starch digestion $(\mathrm{kg} / \mathrm{d} ; P=0.02)$ decreased linearly as dietary TSG content increased; however, when expressed as a proportion of starch intake, apparent ruminal starch digestion was unaffected by the dietary inclusion of DWP. As expected, the partial replacement of barley starch with DWP linearly increased $(P<0.01)$ WSC intake; however, the omasal flow of WSC was not affected by $\operatorname{diet}(P=0.50)$. This resulted in apparent ruminal digestion of WSC $(\mathrm{kg} / \mathrm{d})$ increasing linearly, whereas apparent ruminal digestion of WSC (proportion of WSC intake) responded in a quadratic manner as dietary TSG content increased $(P$ $<0.01)$.

\section{Omasal Flows of Nitrogen Fractions and Bacterial Protein Synthesis}

Nitrogen intake was unaffected $(P=0.40)$ by the dietary inclusion of DWP (Table 5). Both $\mathrm{N}$ truly digested in the rumen ( $\mathrm{g} / \mathrm{d}$ or as \% of $\mathrm{N}$ intake) and RDP supply $(\mathrm{g} / \mathrm{d})$ were unaffected $(P>0.05)$ by the substitution of barley starch with DWP; however, RDP supply when expressed as a proportion of DMI differed among diets $(P=0.03)$. Diet did not affect $(P \geq 0.45)$ RUP supply when expressed as grams per day or as a proportion of DMI. Omasal flow of $\mathrm{N}$ (expressed in $\mathrm{g} / \mathrm{d}$ ) responded in a quadratic manner $(P=0.05$; Figure 3$)$; however, when expressed as a proportion of $\mathrm{N}$ intake, omasal flow of $\mathrm{N}$ tended to respond in a quadratic manner $(P$ $=0.07$; Table 5). For omasal flow of $\mathrm{NH}_{3}-\mathrm{N}$, there was a quadratic response $(P=0.05$; Figure 3$)$ as dietary TSG increased. Omasal flow of NAN, when expressed as grams per day, tended to change quadratically $(P$ $=0.07$; Figure 3$)$ as dietary TSG content increased, whereas when expressed as a percentage of $\mathrm{N}$ intake, it linearly decreased $(P=0.03$; Table 5$)$. The partial substitution of barley starch with DWP did not affect $(P=0.49)$ the omasal flow of NANBN (Figure 3$)$. The dietary inclusion of DWP resulted in a quadratic response $(P=0.04)$ in the omasal flow of FAB NAN 
Table 5. The effects of increasing dietary content of total sugar (TSG) by the partial replacement of barley starch with dried whey permeate on intake, digestibility, and omasal flow of nitrogen constituents in dairy cows $(n=4)$

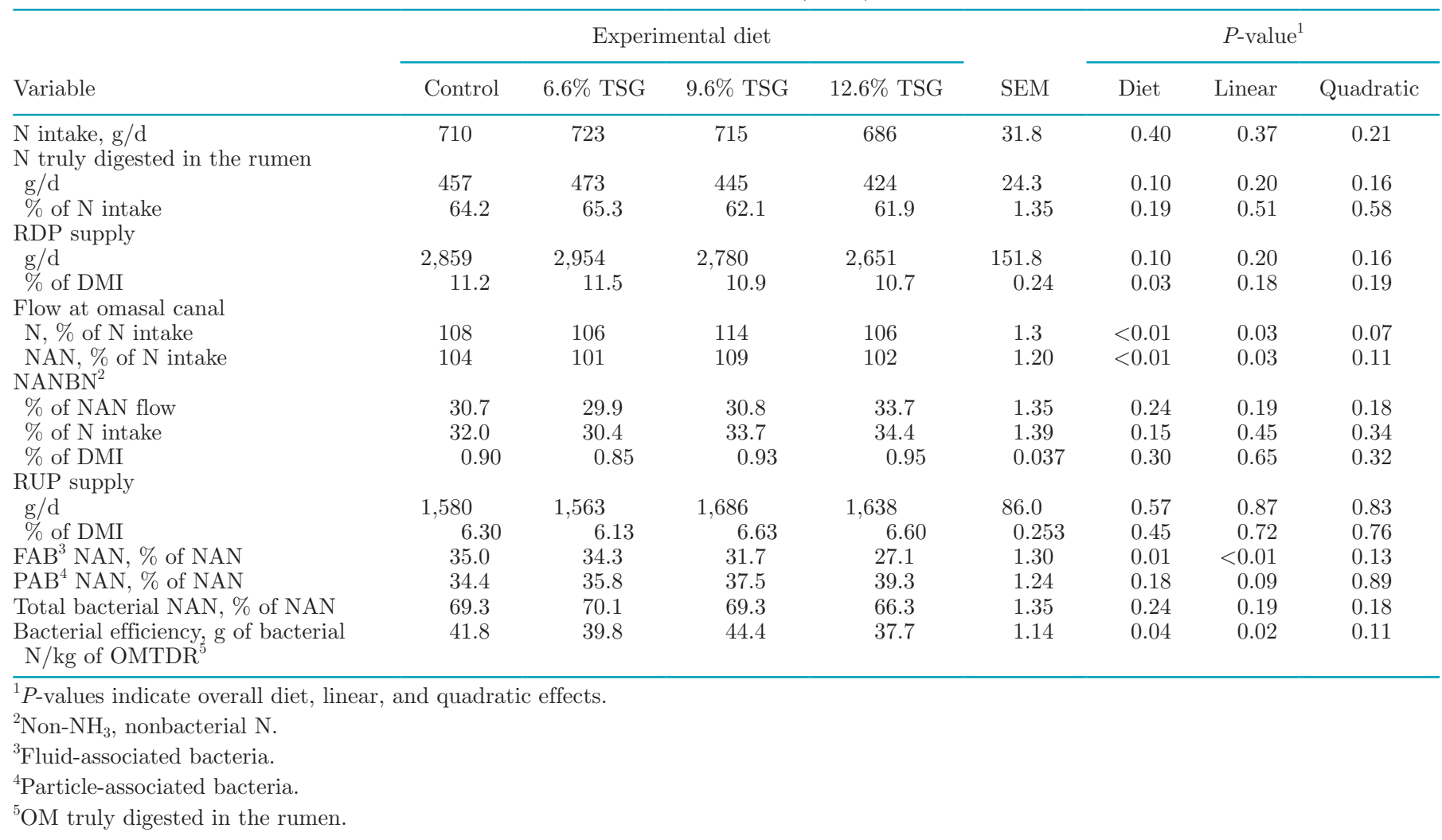

when it was expressed in grams per day (Figure 4); however, when it was expressed as a percentage of NAN, the omasal flow of FAB NAN linearly decreased $(P<0.01$; Table 5$)$. Dietary TSG content did not affect the omasal flow of PAB NAN when expressed as grams per day $(P=0.16$; Figure 3$)$, whereas the omasal flow of PAB NAN expressed as a percentage of NAN tended to increase linearly $(P=0.09$; Table 5$)$ as diet content of DWP increased. Total bacterial NAN omasal flow, expressed as grams per day, responded in a quadratic manner $(P=0.04$; Figure 3$)$ as dietary TSG content increased. Increasing dietary TSG content resulted in a linear decrease $(P=0.02)$ in bacterial $\mathrm{N}$ efficiency.

\section{Apparent Nitrogen Balance and Apparent Total-Tract Nutrient Digestibilities}

Total $\mathrm{N}$ intake was not affected $(P=0.40)$ by the dietary addition of DWP (Table 6). Urinary excretion of total N (g/d; $P=0.02)$ and urea-N $(\mathrm{g} / \mathrm{d} ; P=0.05)$ responded in a quadratic manner, whereas urinary excretion of total $\mathrm{N}$ (\% of $\mathrm{N}$ intake; $P=0.07$ ) tended to respond in a quadratic manner as dietary TSG content increased. When expressed as grams per day $(P$ $=0.01)$ or as a percent of $\mathrm{N}$ intake $(P=0.04)$, fecal
$\mathrm{N}$ excretion linearly increased as dietary TSG content increased. There was a quadratic response $(P=0.03)$ in total $\mathrm{N}$ excretion $(\mathrm{g} / \mathrm{d})$ when dietary TSG content increased. Milk N (g/d or \% of $\mathrm{N}$ intake), apparent $\mathrm{N}$ balance, and productive $\mathrm{N}$ were not affected $(P \geq 0.49)$ by diet. Apparent total-tract digestibilities of DM, OM, ether extract, ADF, NDF, and starch were not affected $(P \geq 0.14)$ by dietary TSG content. We detected a linear decrease $(P=0.05)$ in apparent total-tract $\mathrm{CP}$ digestibility as dietary DWP content increased and a quadratic response $(P=0.01)$ in apparent total-tract digestibility of WSC as dietary TSG content increased.

\section{Whole-Body Urea Kinetics}

The endogenous production of urea (UER; g/d) responded in a quadratic manner $(P=0.02)$ as dietary TSG content increased (Figure 5). Urea-N recycled to the GIT (GER; $P=0.07$ ) and urea-N returned to the ornithine cycle (ROC; $P=0.09$ ) tended to respond in a quadratic manner, whereas urinary excretion of urea-N (UUE) responded in a quadratic manner $(P=$ $0.05)$ as dietary TSG content increased. Urea-N loss to feces (UFE) and urea-N utilized for anabolic purposes (UUA) were unaffected $(P \geq 0.18)$ by diet. Fractional 


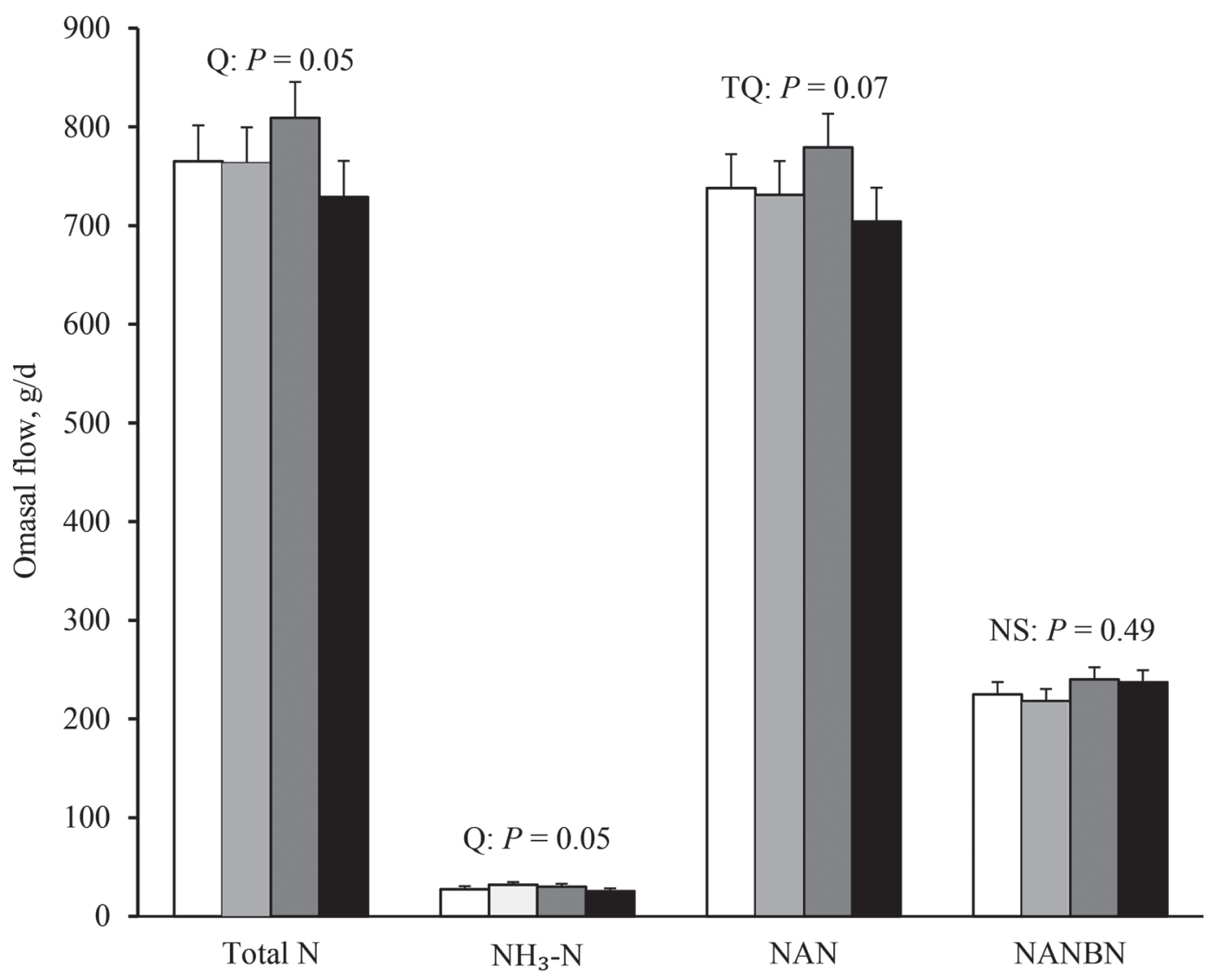

Figure 3. The omasal flows of nitrogenous constituents in dairy cows fed increasing dietary contents of total sugar (TSG) by the partial replacement of barley starch with dried whey permeate (DWP). Dietary treatments were control (no added DWP), $6.6 \%, 9.6 \%$, and $12.6 \%$ TSG. Each data point represents the mean \pm SEM. NANBN $=$ non- $\mathrm{NH}_{3}$, non-bacterial $\mathrm{N} ; \mathrm{Q}=$ quadratic change; TQ $=$ tendency for a quadratic change; and NS = nonsignificant.

transfers of urea-N (i.e., UER to urine or GIT, GER to ROC or UUA) were not affected $(P \geq 0.26)$ by diet, except that the proportion of GER eliminated in feces (i.e., GER to feces) tended to respond in a quadratic manner $(P=0.07)$ as dietary TSG content increased (Table 7). Ruminal bacterial utilization of recycled urea-N (g of N/d or \% of total bacterial NAN) was not affected $(P \geq 0.15)$ by dietary TSG content.

\section{DISCUSSION}

It is pertinent to comment on the diet design that was used in the present study. First, graded TSG contents up to $12.6 \%$ were used. Broderick et al. (2008) reported improved production and $\mathrm{N}$ efficiency when TSG content was increased from 2.7 to $10.0 \%$ of DM using sucrose as a substitute for corn starch in corn silage-based diets. However, in our previous work (Chibisa et al., 2015), we noted no positive effects on pro- duction when the partial replacement of barley starch with DWP increased TSG content from $2.9 \%$ (basal diet) to $8.1 \%$ in barley silage-based diets. These observations suggested that dietary TSG contents of up to $8.1 \%$ might be inadequate to elicit positive responses in production, so that was the rationale for testing TSG contents $>8.1 \%$ in cows fed barley-based diets. Second, to test the effects of dietary TSG content, it was important that diets were isonitrogenous. This was achieved by manipulating the proportions of the 4 major protein sources across diets; however, this approach could have introduced confounding effects of dietary RDP or RUP source, thus making it difficult to determine the sole effects of supplemental sugar. Computations made using the Cornell Net Carbohydrate and Protein System (CNCPS, version 6.5.5.1; http://blogs.cornell.edu/ cncps/purchase/) indicated that the proportions of protein fractions A1 ( $\sim 0.4 \%$ of DM), A2 ( $5.6 \%)$, and C $(\sim 1.1 \%)$ were not altered by dietary composition; 
however, the proportions of protein fractions B1 (7.8, $7.9,8.0$, and $8.2 \%$ of DM for the control, $6.6,9.6$, and $12.6 \%$ TSG diets, respectively) and B2 $(2.2,2.0,1.8$, and $1.5 \%$ ) changed with diet. This would suggest that, as TSG content increased, proteins were shifted from fraction B2 (fiber-bound protein) to the more rapidly degradable fraction B1 because of the change in protein sources. As discussed elsewhere, these shifts in protein fractions could have confounding effects on some of the measures of $\mathrm{N}$ utilization that we reported; however, RDP supply and omasal flow of RUP were not affected by diet, suggesting that the confounding effects of protein source were small.

In the present study, the partial substitution of barley starch with DWP up to $12.5 \%$ TSG content did not affect DMI. Ruminal NDF digestibility is one of the factors that influence DMI in dairy cows; increased ruminal NDF digestibility reduces rumen fill, thus increasing DMI in dairy cows (Oba and Allen, 1999). However, we did not observe differences in apparent ruminal NDF digestibility across diets, which could partly explain why DMI was unaffected by diet. These findings are consistent with those reported by Chibisa et al. (2015) when DWP was included in barley- or corn-based diets. Also, the dietary inclusion of pure lactose up to $15.7 \%$ in corn-based diets did not affect DMI in dairy cows (DeFrain et al., 2006). In contrast, dietary inclusion of sucrose (Broderick and Radloff, 2004; Broderick et al., 2008; Penner and Oba, 2009) or lactose (DeFrain et al., 2004) as a partial replacement for corn starch improved DMI in dairy cows. Moreover, partial substitution of barley starch with sucrose up to $9.3 \%$ TSG quadratically altered DMI in dairy cows (Khorvash et al., 2014). The reasons for the discrepant observations in DMI when feeding sugars are not clear but could be related to such factors as differences in basal dietary composition and level of intake. Milk yields were similar across diets. Dry matter intake has a positive correlation with milk production (NRC, 2001); therefore, it was not surprising to observe similar milk

\section{$\square$ Control $\square 6.6 \%$ TSG $\quad \square 9.6 \%$ TSG $\square 12.6 \%$ TSG}

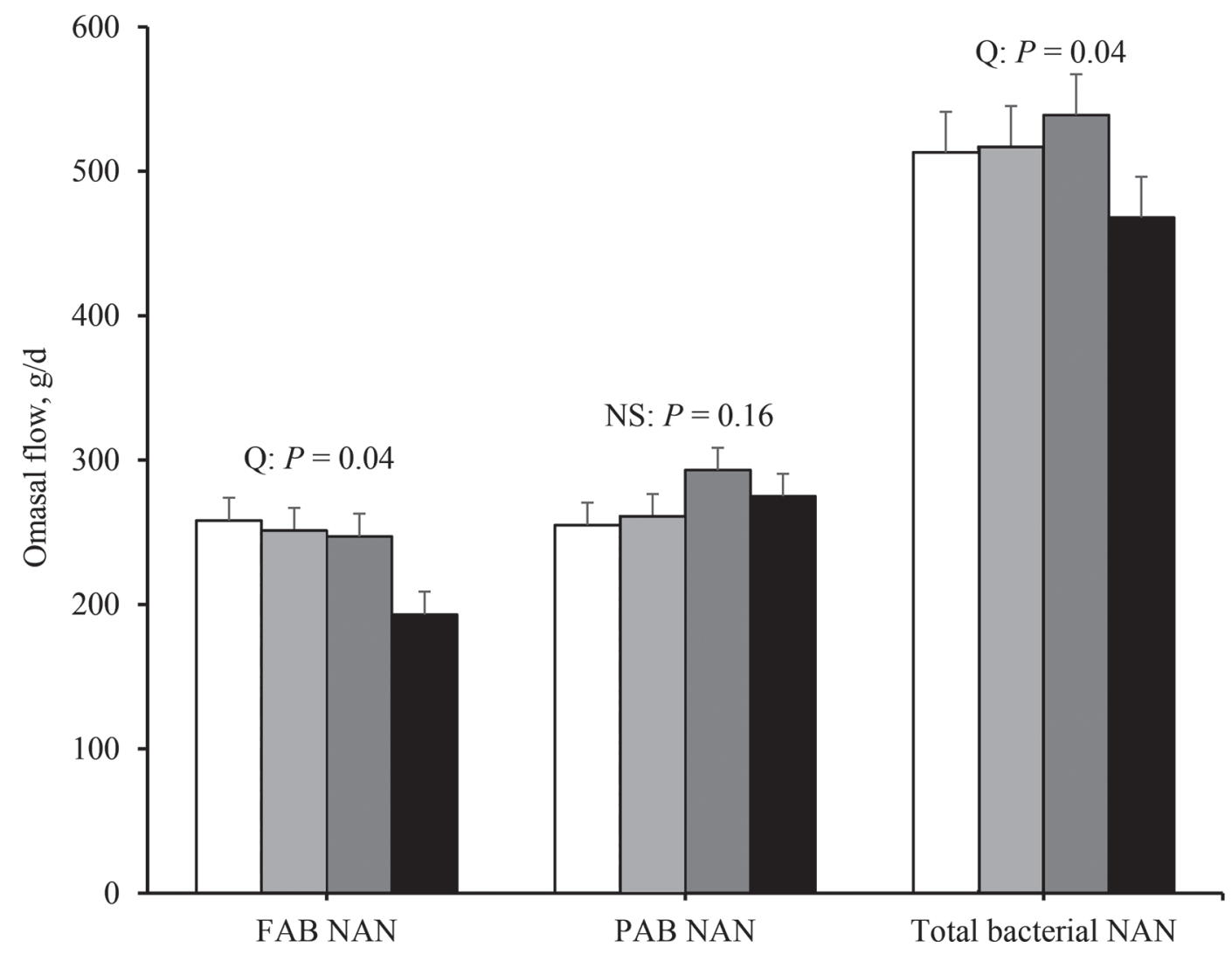

Figure 4. The omasal flows of bacterial NAN in dairy cows fed increasing dietary contents of total sugar (TSG) by the partial replacement of barley starch with dried whey permeate (DWP). Dietary treatments were control (no added DWP), 6.6\%, 9.6\%, and 12.6\% TSG. Each data point represents the mean $\pm \mathrm{SEM} . \mathrm{FAB}=$ fluid-associated bacteria; $\mathrm{PAB}=$ particle-associated bacteria; total bacterial $\mathrm{NAN}=\mathrm{FAB} \mathrm{NAN}+$ PAB NAN; $\mathrm{Q}=$ quadratic change; and NS = nonsignificant. 
yields in the present study because DMI was unaffected by diet. Based on computations made using CNCPS (version 6.5.5.1), the experimental diets supplied adequate $\mathrm{NE}_{\mathrm{L}}$ to support $42 \mathrm{~kg} / \mathrm{d}$ of milk yield; therefore, it is unlikely that $\mathrm{NE}_{\mathrm{L}}$ supply limited production as mean milk yield for cows that were used in the present study was $34.9 \mathrm{~kg} / \mathrm{d}$. In agreement with our results, dietary inclusion of lactose or sucrose did not influence milk yield in dairy cows fed barley- or corn-based diets (DeFrain et al., 2004; Khorvash et al., 2014; Chibisa et al., 2015). However, Broderick and Radloff (2004) observed quadratic changes in milk yield when sucrose (fed liquid molasses) partially replaced corn starch up to $10 \%$ TSG level. Concomitantly, DMI was quadratically changed by feeding sucrose, so the positive response in milk yield could be partly attributed to changes in DMI.

The dietary addition of DWP had no effects on milk fat content and fat yield. Ruminally derived acetate and plasma $\mathrm{BHB}$ are major precursors for de novo milk fat synthesis in the mammary gland (Bauman and Griinari, 2003). Concentrations of ruminal acetate and plasma BHB were not altered by diet in the present study, which could partly explain why milk fat con- tent and yield were unaffected. Similarly, other studies (DeFrain et al., 2004; Penner et al., 2009; Chibisa et al., 2015) observed that milk fat content or yield were unaffected in cows fed diets that contained added sugars. Contrary to these results, Broderick et al. (2008) reported a linear increase in milk fat content and yield when dietary sucrose content was increased up to $10 \%$ TSG in corn-based diets. Moreover, Broderick and Radloff (2004) observed a quadratic increase in milk fat yield peaking at $4.2 \%$ TSG when liquid molasses partially substituted corn starch. In agreement with the milk fat response, milk protein content and yield were unaffected by diet. Amino acids to support milk protein synthesis are primarily derived from the postruminal digestion of microbial protein that is synthesized in the rumen (NRC, 2001). As discussed elsewhere, total bacterial NAN flow changed quadratically as dietary content of DWP increased, but this had no influence on milk protein content or yield. Amino acids that are derived from postruminal digestion of microbial protein can be directed toward uses within the body (e.g., growth) other than milk protein synthesis, which could partly explain why the changes in bacterial NAN flow were not accompanied by similar changes in milk

Table 6. The effects of increasing dietary content of total sugar (TSG) by the partial replacement of barley starch with dried whey permeate on apparent nitrogen balance and apparent total-tract nutrient digestibility in dairy cows $(n=4)$

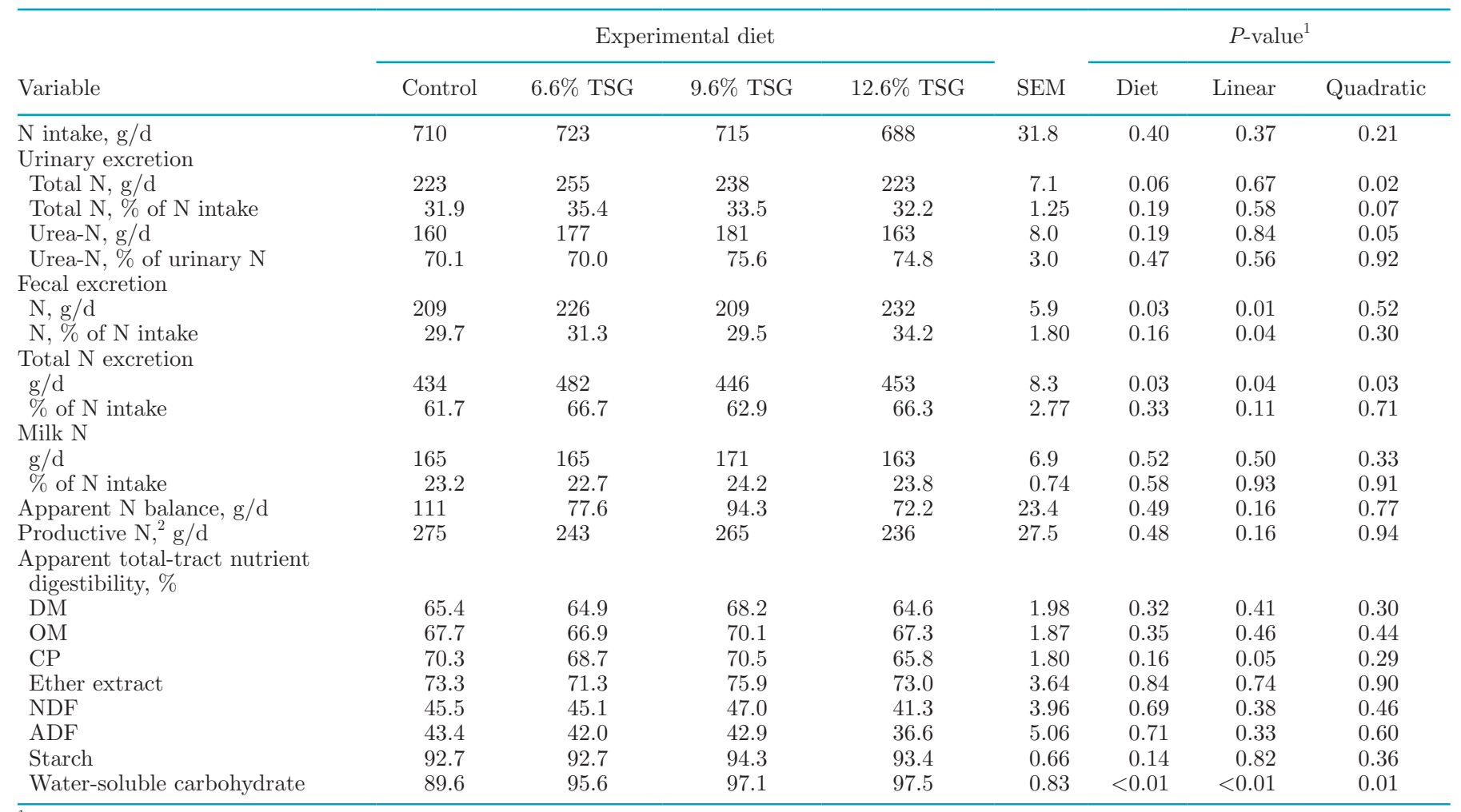

${ }^{1} P$-values indicate overall diet, linear, and quadratic effects.

${ }^{2}$ Calculated as $\mathrm{N}$ secreted in the milk $+\mathrm{N}$ apparently retained by the cow. 
Table 7. The effects of increasing dietary content of total sugar (TSG) by the partial replacement of barley starch with dried whey permeate on whole-body urea- $\mathrm{N}$ fractional transfers $(\mathrm{n}=4)$

\begin{tabular}{|c|c|c|c|c|c|c|c|c|}
\hline \multirow[b]{2}{*}{ Variable } & \multicolumn{4}{|c|}{ Experimental diet } & \multirow[b]{2}{*}{ SEM } & \multicolumn{3}{|c|}{$P$-value ${ }^{1}$} \\
\hline & Control & $6.6 \% \mathrm{TSG}$ & $9.6 \% \mathrm{TSG}$ & $12.6 \% \mathrm{TSG}$ & & Diet & Linear & Quadratic \\
\hline UER to urine & 0.341 & 0.335 & 0.350 & 0.354 & 0.0179 & 0.85 & 0.76 & 0.74 \\
\hline UER to GIT & 0.659 & 0.665 & 0.650 & 0.646 & 0.0179 & 0.85 & 0.76 & 0.74 \\
\hline GER to ROC & 0.850 & 0.833 & 0.873 & 0.886 & 0.0199 & 0.31 & 0.46 & 0.46 \\
\hline GER to feces & 0.036 & 0.033 & 0.032 & 0.042 & 0.0028 & 0.18 & 0.20 & 0.07 \\
\hline $\mathrm{g}$ of $\mathrm{N} / \mathrm{d}$ & 81.3 & 69.5 & 84.5 & 75.0 & 5.76 & 0.15 & 0.20 & 0.82 \\
\hline$\%$ of total bacterial NAN & 15.8 & 13.7 & 15.8 & 15.9 & 0.65 & 0.59 & 0.19 & 0.17 \\
\hline
\end{tabular}

${ }^{1} P$-values indicate overall diet, linear, and quadratic effects.

${ }^{2} \mathrm{UER}=$ urea-N entry rate; GIT $=$ gastrointestinal tract; GER $=$ gastrointestinal entry rate; $\mathrm{ROC}=$ urea-N returned to ornithine cycle; UUA $=$ urea-N utilized for anabolism.

${ }^{3}$ Calculated according to Wickersham et al. (2009).

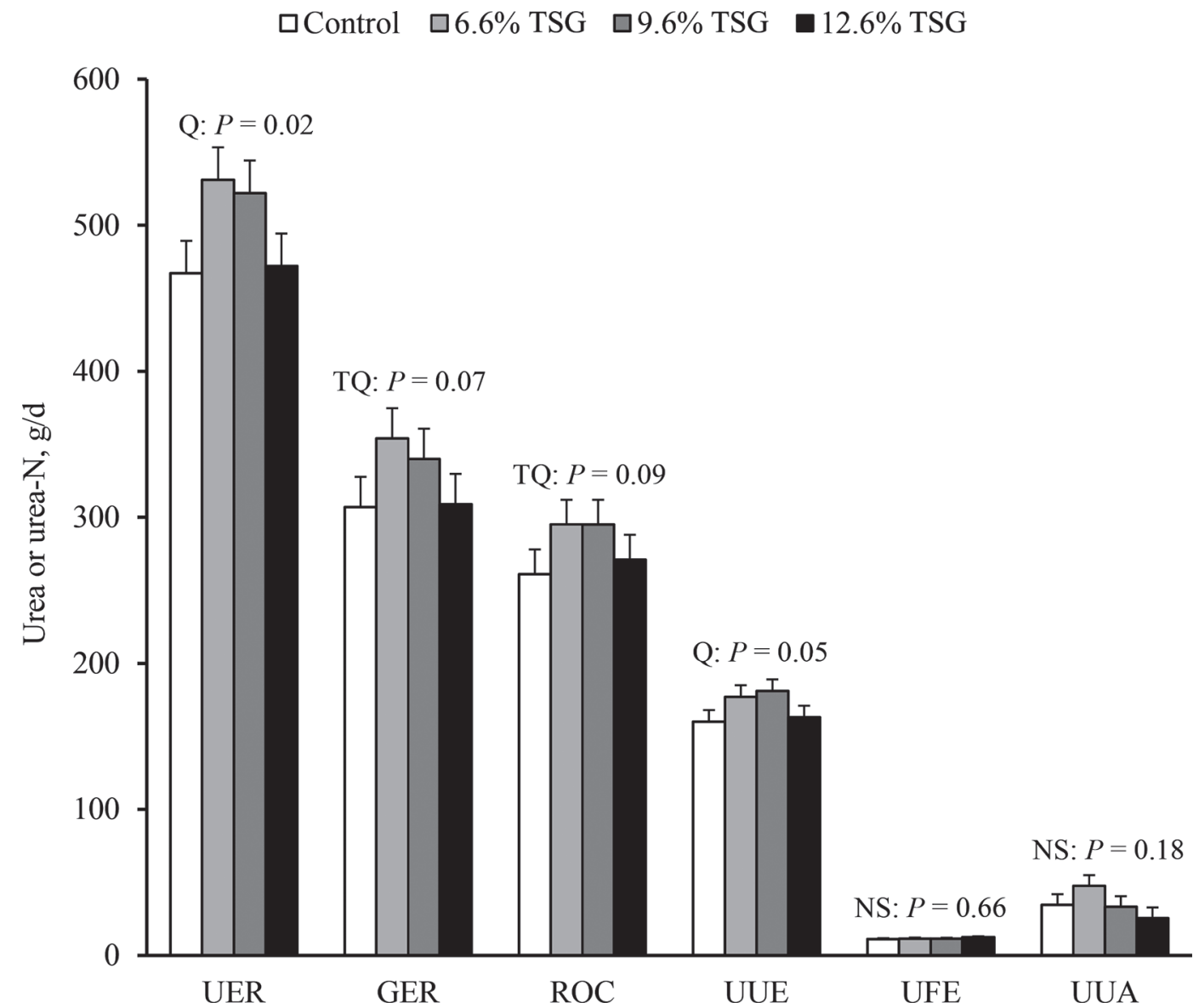

Figure 5. Whole-body urea-N kinetics in dairy cows fed increasing dietary contents of total sugar (TSG) by the partial replacement of barley starch with dried whey permeate (DWP). Dietary treatments were control (no added DWP), 6.6\%, 9.6\%, and 12.6\% TSG. Each data point represents the mean \pm SEM. UER $=$ endogenous production of urea; GER $=$ urea-N recycled to the gastrointestinal tract; $\mathrm{ROC}=$ urea- $\mathrm{N}$ returned to the ornithine cycle; UUE = urinary urea-N excretion; UFE = urea-N excretion in feces; UUA = urea-N utilized for anabolism; $\mathrm{Q}=$ quadratic change; $\mathrm{TQ}=$ tendency for a quadratic change; and NS = nonsignificant. 
protein content or yield. Consistent with our findings, several authors have reported no response in milk protein content to increased dietary TSG content (DeFrain et al., 2006; Khorvash et al., 2014; Chibisa et al., 2015), although Broderick and Radloff (2004) reported a quadratic response to increased dietary molasses content in corn-based diets.

A major objective of the present study was to delineate the effects of partial substitution of barley starch with DWP on whole-body urea kinetics. Our results showed that endogenous production of urea (i.e., UER) quadratically changed as dietary TSG concentration increased, with peak urea flux attained at 9.6\% TSG level. Numerous studies have demonstrated a positive correlation between $\mathrm{N}$ intake and UER (Reynolds et al., 1994; Lapierre et al., 2000; Marini and Van Amburgh, 2003); however, in contrast to the observed dietary effects on UER in the present study, $\mathrm{N}$ intake was not influenced by diet. In ruminants, ruminally derived $\mathrm{NH}_{3}$ is the major contributor of $\mathrm{N}$ for hepatic ureagenesis (Reynolds and Huntington, 1988); because portal absorption of $\mathrm{NH}_{3}$ is concentration-dependent, ruminal $\mathrm{NH}_{3}$ concentration is positively correlated with hepatic output of urea. However, in the present study, quadratic changes in UER did not mirror the observed linear decrease in ruminal $\mathrm{NH}_{3}-\mathrm{N}$ concentration. The reasons for this discrepancy are unclear, but it is noteworthy that the numerical trends in changes in N intake and UER as dietary level of TSG increased were similar. Also, other sources of $\mathrm{N}$ (e.g., $\mathrm{N}$ derived from AA catabolism in skeletal muscle) can contribute to ureagenesis (Stewart and Smith, 2005), and we did not assess that in the present study. Across dietary treatments, UER ranged from 467 to $531 \mathrm{~g} / \mathrm{d}$ with the UER:N intake ratios ranging from 0.66 to 0.73 . These UER: $N$ intake ratios indicate that considerable amounts of $\mathrm{N}$ transit through the body pool of urea daily, signifying the importance of urea recycling to the $\mathrm{N}$ economy of ruminants. For lactating cows at various levels of production and fed a wide variety of diets, UER:N intake ratios of 0.43 to 1.23 (mean $=0.88$ ) have been reported previously (Lapierre and Lobley, 2001), and this range encompasses the ratios observed in the present study. Gozho et al. (2008; 0.72 to 1.06) and Chibisa and Mutsvangwa (2013; 0.61 to 0.64) have reported similar UER:N intake ratios in studies with dairy cows at similar levels of $\mathrm{N}$ intake and milk production.

Our results indicated a quadratic response in GER (i.e., endogenous urea-N output that enters the GIT), with GER increasing as dietary DWP content was elevated up to $9.6 \%$ TSG before declining at $12.6 \%$ TSG to a level that was similar to that of the control diet. There is a positive correlation between UER and GER
(Archibeque et al., 2001; Marini et al., 2004), so the quadratic response in GER reflects that observed in UER. The mechanism(s) involved in this tendency for a decrease in GER at $12.6 \%$ TSG are unclear but could be related to changes in ruminal $\mathrm{pH}$ as dietary NSC content increased. Abdoun et al. (2010) varied mucosal $\mathrm{pH}$ in Ussing chambers from 5.4 to 7.4 and observed a bell-shaped response in net urea flux, with peak flux attained at a mucosal $\mathrm{pH}$ of 6.2.In the present study, mean ruminal $\mathrm{pH}$ values for the control, 6.6, 9.6, and $12.6 \%$ TSG diets were $6.32,6.31,6.34$, and 6.22 , respectively, which indicates that the greatest urea flux into the GIT was attained at a mean ruminal $\mathrm{pH}$ of 6.31 to 6.34. These results might suggest that the optimum $\mathrm{pH}$ for maximal urea secretion from the bloodstream into the rumen is different from that suggested based on in vitro studies (i.e., $\mathrm{pH}$ of 6.2 ).

The dietary inclusion of DWP did not affect the amount of recycled urea-N that was utilized for anabolic purposes (i.e., UUA, mean $=35.1 \mathrm{~g} / \mathrm{d}$ ). Bacterial capture of $\mathrm{NH}_{3}-\mathrm{N}$ derived from urea- $\mathrm{N}$ is the primary mechanism of utilizing recycled urea-N for anabolic purposes (Lobley et al., 2000). In the present study, bacterial capture of recycled urea-N (mean $=77.6 \mathrm{~g} / \mathrm{d}$ ) was similar across diets; however, bacterial capture of recycled urea-N was greater than UUA. In the model described by Lobley et al. (2000), UUA is calculated as GER - (ROC + UFE). However, the fraction of microbial AA that is not digested and absorbed by the animal, and the microbial AA that were absorbed and subsequently catabolized without being utilized by the host for protein deposition are not included in the calculation of UUA in that model. Therefore, this is likely to explain the difference between bacterial capture of recycled N and UUA (Wickersham et al., 2009). In addition, because UUA is calculated by difference, any errors (e.g., incomplete recovery of urinary N) that occur in the measurement of any of the 3 variables that are included in this calculation will be reflected in the $\mathrm{N}$ balance data. Also, fecal ${ }^{15} \mathrm{~N}$ enrichment failed to attain a definite plateau with 4-d isotopic infusions; therefore, it is likely that UFE was underestimated, which would then result in underestimation of UUA (Lobley et al., 2000). In the present study, bacterial capture of recycled $\mathrm{N}$ ranged from 13.7 to $15.9 \%$, which lies within the range of 8.5 to $25 \%$ that has been reported in dairy cows (Ouellet et al., 2002, 2010; Lapierre et al., 2008; Chibisa and Mutsvangwa, 2013).

The omasal flow of PAB NAN was not influenced by diet; however, we observed a quadratic response in the omasal flow of FAB NAN as it was similar on the control and 6.6 and 9.6\% TSG diets but declined on the $12.6 \%$ TSG diet. Similar trends were observed for the omasal flow of total bacterial NAN, which reflected 
the observed changes in FAB NAN flow. The reason(s) for the observed response in FAB NAN flow is unclear, but it could be related to the accumulation of reserve carbohydrates by ruminal microorganisms as the dietary content of soluble carbohydrates increased. When there is a plentiful supply of soluble carbohydrates in the rumen (i.e., immediately after feeding), both bacteria and protozoa will accumulate large amounts of reserve carbohydrates primarily as glycogen (Preiss and Romeo, 1989). For example, when mixed ruminal microbes were dosed with 5 to $20 \mathrm{~m} M$ glucose, 30 to $50 \%$ of the glucose carbon was incorporated into reserve carbohydrates (Hackmann et al., 2013; Denton et al., 2015). Although the reserve carbohydrates can be fermented to provide ATP for microbial growth later in the feeding cycle, the amount of ATP that is provided is reduced because the synthesis of reserve carbohydrates is energetically expensive (Denton et al., 2015). Based on CNCPS (version 6.5.5.1) computations, the dietary proportion of carbohydrate fraction A4 (i.e., sugars) was 5.3, 8.4, 11.3, and $14.4 \%$ of DM as dietary content of DWP increased. Also, ruminal digestion of WSC increased as the dietary content of DWP increased. Collectively, these data suggest an increasing availability of soluble carbohydrates (primarily lactose, which is the major carbohydrate in DWP) as dietary DWP content increased. Therefore, although we did not measure the accumulation of reserve carbohydrates in ruminal microbes in the present study, it is plausible that the amount of dietary carbohydrate that passed through the reserve carbohydrate pool increased as dietary DWP content was increased, reaching a peak at $12.6 \%$ TSG. Because FAB are more dependent on soluble carbohydrates for energy supply than PAB (Cheng and McAllister, 1997), greater sequestration of soluble carbohydrates as reserve carbohydrates could have a greater negative effect on FAB than on PAB. One notable contribution of this paper is the addition of data on the extent of ruminal digestion and omasal flow of WSC, as we are not aware of any published papers that have reported such data when dietary starch is substituted with a source of sugar. Dietary sugars are assumed to be rapidly degraded in the rumen (Broderick et al., 2008; Van Amburgh et al., 2015), but our data indicate that 425 to $525 \mathrm{~g} / \mathrm{d}$ of WSC escaped ruminal digestion, which represented 12 to $48 \%$ of dietary WSC intake.

Dietary RDP supply can also influence ruminal microbial protein production (Bach et al., 2005). As discussed elsewhere, diets differed in their relative proportions of protein fractions $\mathrm{B} 1$ and $\mathrm{B} 2$, with fraction $\mathrm{B} 1$ increasing and fraction B2 decreasing as dietary TSG content increased. Soluble proteins are mainly associated with the fluid phase in the rumen; therefore, considerable amounts of soluble proteins of dietary origin can escape ruminal degradation (NRC, 2001; Choi et al., 2002; Reynal et al., 2007), thereby not contributing to the ruminal pools of AA and peptides. Although ruminal AA and peptide pools were not measured, we can speculate that these pools could have diminished as TSG content increased because of greater ruminal escape of soluble proteins. The linear decrease in ruminal $\mathrm{NH}_{3}-\mathrm{N}$ concentration as TSG content increased provides indirect evidence of this assertion. It is plausible, therefore, that the decrease in FAB NAN flow with the $12.6 \%$ TSG diet could be partly attributable to reduced availability of AA and peptides because it was the diet with the greatest protein solubility. Reports in the literature depict inconsistent responses in MPS when cereal grains are substituted with sugars. Chamberlain et al. (1993) and Kim et al. (1999) observed an increase in duodenal flow of microbial $\mathrm{N}$ when sugars were added to grass silage-based diets that were fed to lactating cows, whereas Broderick et al. (2008) observed that duodenal microbial $\mathrm{N}$ flow was not affected when corn starch was partially replaced with sucrose up to $10 \%$ dietary TSG level. However, Sannes et al. (2002) reported a decrease in microbial protein flow when $3 \%$ sucrose was added to corn-based lactating diets.

For measures relating to productive $\mathrm{N}$ efficiency such as milk $\mathrm{N}$ efficiency (calculated as milk $\mathrm{N} / \mathrm{N}$ intake) and $\mathrm{N}$ balance, our results showed that increasing DWP intake was not accompanied by improved $\mathrm{N}$ use. Milk N efficiency was unaffected by diet, supporting previous findings with sugar supplementation of barleybased diets (Chibisa et al., 2015). In contrast, results with corn-based diets indicated a positive effect of supplemental sugar on milk N efficiency (Broderick and Radloff, 2004; Broderick et al., 2008), suggesting that the response to supplemental sugar might depend, inter alia, on the type of cereal grain that is being replaced. Nitrogen balance was also unaffected by diet, which agrees with previous findings (Chibisa et al., 2015). Our results showed that mean $\mathrm{N}$ balance across diets was $88 \mathrm{~g} / \mathrm{d}$, which would convert to a protein gain of $550 \mathrm{~g} / \mathrm{d}$. Assuming that the body protein:water ratio is 1:3 (Spanghero and Kowalski, 1997), this protein gain is equivalent to a lean tissue gain of $2.2 \mathrm{~kg} / \mathrm{d}$, which is rather unrealistic for lactating dairy cows. We calculated $\mathrm{N}$ balance as $\mathrm{N}$ intake - (milk $\mathrm{N}+$ fecal $\mathrm{N}+$ urine $\mathrm{N}$ ); therefore, any errors that occur in the measurement of any of the 4 variables that are included in this calculation will be reflected in the $\mathrm{N}$ balance data. Generally, N balance data are inherently flawed because the methodologies used often result in unaccountable $\mathrm{N}$ losses of unknown magnitude (e.g., loss of volatile N-containing material during oven drying of feces; Spanghero and Kowalski, 1997), so N balance data 
should be interpreted somewhat cautiously. We also observed that PUN and MUN concentrations (which are useful indicators of $\mathrm{N}$ efficiency) were unaffected by diet. This observation is not surprising because MUN is known to be highly correlated with PUN concentration (Roseler et al., 1993). In ruminants, PUN is mostly synthesized from ruminally derived $\mathrm{NH}_{3}-\mathrm{N}$ (Reynolds and Huntington, 1988). Because ruminal $\mathrm{NH}_{3}-\mathrm{N}$ concentration decreased as TSG content increased, it was somewhat surprising that parallel changes were not observed in PUN concentrations. The reason for this discrepancy is unclear, but ruminal $\mathrm{NH}_{3}-\mathrm{N}$ concentration does not truly reflect $\mathrm{NH}_{3}-\mathrm{N}$ production because it represents a balance between production and disappearance (Broderick et al., 2008).

Of the key ruminal fermentation characteristics that we measured, we observed significant effects of DWP supplementation on $\mathrm{NH}_{3}-\mathrm{N}$ and butyrate concentrations. The dietary inclusion of DWP resulted in a linear decrease in ruminal concentration of $\mathrm{NH}_{3}-\mathrm{N}$, which concurs with previous studies with diets based on grass silage (Chamberlain et al., 1993; Kim et al., 1999), corn (Sannes et al., 2002; Broderick et al., 2008) or barley (Chibisa et al., 2015). Feeding more rapidly fermented sugars than starch can reduce ruminal $\mathrm{NH}_{3}$ $\mathrm{N}$ concentration by providing more energy for microbial sequestration of peptides, $\mathrm{AA}$, and $\mathrm{NH}_{3}-\mathrm{N}$ that are derived from dietary and endogenous $\mathrm{N}$ sources (Russell et al., 1992). In addition, increasing dietary ruminally fermentable carbohydrate content enhances the growth of amylolytic bacteria that utilize preformed AA and peptides as preferred $\mathrm{N}$ sources for protein synthesis; consequently, the greater microbial use of preformed peptides and AA would reduce their ruminal catabolism, reducing ruminal $\mathrm{NH}_{3}-\mathrm{N}$ concentration (Hristov et al., 2004). We also observed a linear increase in ruminal concentration of butyrate as dietary TSG content increased, which concurs with previous studies with lactose supplementation (DeFrain et al., 2004, 2006; Chibisa et al., 2015). However, increasing dietary sucrose content did not affect ruminal concentration of butyrate in cows (Broderick et al., 2008; Penner and Oba, 2009; Khorvash et al., 2014). These discrepant findings may suggest a partial shift in ruminal fermentation of lactose toward production of butyrate in cows fed diets that contain lactose as a sugar source. Butyrate is the primary energy source for ruminal epithelial cells (Bergman, 1990), with its metabolism producing $\mathrm{BHB}$, which is subsequently absorbed into portal blood. Several studies have reported increases in both butyrate and plasma BHB concentrations when corn starch was partially replaced with lactose (DeFrain et al., 2004, 2006). However, changes in ruminal butyrate concentration in the present study were not associated with changes in plasma BHB concentration. Other than ruminal epithelial metabolism of butyrate, hepatic metabolism of both acetoacetate and fatty acids derived from adipose tissue catabolism can contribute to plasma BHB pools (Kristensen, 2005). Penner and Oba (2009) detected an increase in plasma BHB concentration without a change in ruminal butyrate concentration in transition cows fed sucrose, suggesting that ruminal butyrate and plasma BHB concentrations do not always change simultaneously. Also, Chibisa et al. (2015) did not observe an increase in plasma BHB levels even though ruminal butyrate concentration was increased when cows were fed lactose in corn- or barleybased diets.

\section{CONCLUSIONS}

Feeding sugars such as lactose or sucrose as a partial replacement for corn grain starch has been reported to improve milk production in dairy cows; however, our results indicate that milk production was not improved when DWP (a rich source of lactose) replaced barley grain starch. The lack of a lactational response to the dietary addition of DWP was likely due to unaffected DMI. These results imply that production responses might depend on the type of cereal grain starch that is being replaced with sugars. Our results also showed that feeding DWP as a partial replacement for barley starch resulted in a linear decrease in ruminal $\mathrm{NH}_{3}-\mathrm{N}$ concentration, which might indicate improved ruminal $\mathrm{N}$ utilization. However, other factors related to improved $\mathrm{N}$ utilization such as bacterial NAN flow out of the rumen and urea-N recycling to the rumen increased as dietary DWP content increased up to $9.6 \%$ TSG before decreasing at $12.6 \%$ TSG (quadratic response). These results suggest that, although rumen $\mathrm{NH}_{3}-\mathrm{N}$ utilization might improve with feeding incremental amounts of DWP, including TSG beyond 9.6\% might have negative effects on some factors related to $\mathrm{N}$ utilization. Overall, results from this study indicate that feeding incremental amounts of DWP as a partial replacement for barley grain starch had no positive effects on milk protein secretion and $\mathrm{N}$ balance.

\section{ACKNOWLEDGMENTS}

The authors gratefully acknowledge the Government of Saskatchewan (Agricultural Development Fund, ADF) for their financial support. We also express our gratitude to the staff of the Rayner Dairy Research and Teaching Facility (University of Saskatchewan) for their excellent support and animal care throughout the research study. 


\section{REFERENCES}

Abdoun, K., F. Stumpff, I. Rabbani, and H. Martens. 2010. Modulation of urea transport across sheep rumen epithelium in vitro by SCFA and $\mathrm{CO}_{2}$. Am. J. Physiol. Gastrointest. Liver Physiol. 298:G190-G202.

Ahvenjärvi, S., A. Vanhatalo, P. Huhtanen, and T. Varvikko. 2000. Determination of reticulo-rumen and whole-stomach digestion in lactating cows by omasal canal or duodenal sampling. Br. J. Nutr. 83:67-77.

AOAC. 1990. Official Methods of Analysis. 15th ed. Assoc. Offic. Agric. Chem., Arlington, VA.

AOAC International. 2000. Official Methods of Analysis. 17th ed. AOAC International, Arlington, VA.

AOAC International. 2006. Official Methods of Analysis. 18th ed. AOAC International, Arlington, VA.

Archibeque, S. L., J. C. Burns, and G. B. Huntington. 2001. Urea flux in beef steers: Effects of forage species and nitrogen fertilization. J. Anim. Sci. 79:1937-1943.

Bach, A., S. Calsamiglia, and M. D. Stern. 2005. Nitrogen metabolism in the rumen. J. Dairy Sci. 88(E. Suppl.):E9-E21.

Bauman, D. E., and J. M. Griinari. 2003. Nutritional regulation of milk fat synthesis. Annu. Rev. Nutr. 23:203-227.

Bergman, E. N. 1990. Energy contributions of volatile fatty acids from the gastrointestinal tract in various species. Physiol. Rev. 70:567-590.

Broderick, G. A., and J. H. Kang. 1980. Automated simultaneous determination of ammonia and total amino acids in ruminal fluid and in vitro media. J. Dairy Sci. 63:64-75.

Broderick, G. A., N. D. Luchini, S. M. Reynal, G. A. Varga, and V. A. Ishler. 2008. Effect on production of replacing dietary starch with sucrose in lactating dairy cows. J. Dairy Sci. 91:4801-4810.

Broderick, G. A., and W. J. Radloff. 2004. Effect of molasses supplementation on the production of lactating dairy cows fed diets based on alfalfa and corn silage. J. Dairy Sci. 87:2997-3009.

Canadian Council on Animal Care. 2009. CCAC Guidelines on the Care and Use of Farm Animals in Research, Teaching and Testing. Ottawa, ON, Canada.

Chamberlain, D. G., S. Robertson, and J. J. Choung. 1993. Sugars versus starch as supplements to grass silage: Effects on ruminal fermentation and the supply of microbial protein to the small intestine, estimated from the urinary excretion of purine derivatives, in sheep. J. Sci. Food Agric. 63:189-194.

Chase, L. E., R. J. Higgs, and M. E. Van Amburgh. 2009. Feeding low crude protein rations to dairy cows-opportunities and challenges. Pages 220-226 in Proc. 2009 Cornell Nutr. Conf. for Feed Manufacturers. Syracuse, NY. Cornell University, Ithaca, NY.

Cheng, K.-J., and T. A. McAllister. 1997. Compartmentation in the rumen. Pages 492-518 in The Rumen Microbial Ecosystem. 2nd ed. P. N. Hobson, and C. S. Stewart, ed. Blackie Academic and Professional, New York, NY.

Chibisa, G. E., P. Gorka, G. B. Penner, R. Berthiaume, and T. Mutsvangwa. 2015. Effects of partial replacement of dietary starch from barley or corn with lactose on ruminal function, short-chain fatty acid absorption, nitrogen utilization, and production performance of dairy cows. J. Dairy Sci. 98:2627-2640.

Chibisa, G. E., and T. Mutsvangwa. 2013. Effects of feeding wheat or corn-wheat dried distillers grains with solubles in low- or highcrude protein diets on ruminal function, omasal nutrient flows, urea-N recycling, and performance in cows. J. Dairy Sci. 96:65506563.

Choi, C. W., S. Ahvenjärvi, A. Vanhatalo, V. Toivonen, and P. Huhtanen. 2002. Quantitation of the flow of soluble non-ammonia nitrogen entering the omasal canal of dairy cows fed grass silage based diets. Anim. Feed Sci. Technol. 96:203-220.

Crutchfield, W. O. 1968. A technique for the placement of an indwelling catheter in the cow. Vet. Med. Small Anim. Clin. 63:1141-1144.

DeFrain, J. M., A. R. Hippen, K. F. Kalscheur, and D. J. Schingoethe. 2004. Feeding lactose increases ruminal butyrate and plasma $\beta$-hydroxybutyrate in lactating dairy cows. J. Dairy Sci. $87: 2486-2494$
DeFrain, J. M., A. R. Hippen, K. F. Kalscheur, and D. J. Schingoethe. 2006. Feeding lactose to increase ruminal butyrate and the metabolic status of transition dairy cows. J. Dairy Sci. 89:267-276.

Denton, B. L., L. E. Diese, J. L. Firkins, and T. J. Hackmann. 2015. Accumulation of reserve carbohydrate by rumen protozoa and bacteria in competition for glucose. Appl. Environ. Microbiol. $81: 1832-1838$

Fawcett, J. K., and J. E. Scott. 1960. A rapid and precise method for the determination of urea. J. Clin. Pathol. 13:156-159.

France, J., and R. C. Siddons. 1986. Determination of digesta flow by continuous marker infusion. J. Theor. Biol. 121:105-119.

Gozho, G. N., M. R. Hobin, and T. Mutsvangwa. 2008. Interactions between barley grain processing and source of supplemental dietary fat on nitrogen metabolism and urea-nitrogen recycling in dairy cows. J. Dairy Sci. 91:247-259.

Hackmann, T. J., L. E. Diese, and J. L. Firkins. 2013. Quantifying the responses of mixed rumen microbes to excess carbohydrate. Appl. Environ. Microbiol. 79:3786-3795.

Hall, M. B. 2009. Determination of starch, including maltooligosaccharides, in animal feeds: comparison of methods and a method recommended for AOAC collaborative study. J. AOAC Int. 92:42-49.

Hall, M. B. 2014. Selection of an empirical detection method for determination of water-soluble carbohydrates in feedstuffs for application in ruminant nutrition. Anim. Feed Sci. Technol. 198:28-37.

Hristov, A. N., R. P. Etter, J. K. Ropp, and K. L. Grandeen. 2004 Effect of dietary crude protein level and degradability on ruminal fermentation and nitrogen utilization in lactating dairy cows. J. Anim. Sci. 82:3219-3229.

Huhtanen, P., P. G. Brotz, and L. D. Satter. 1997. Omasal sampling technique for assessing fermentative digestion in the forestomach of dairy cows. J. Anim. Sci. 75:1380-1392.

Huhtanen, P., K. Kaustell, and S. Jaakkola. 1994. The use of internal markers to predict total digestibility and duodenal flow of nutrients in cattle given six different diets. Anim. Feed Sci. Technol. 48:211-227.

Huntington, G. B. 1989. Hepatic urea synthesis and site and rate of urea removal from blood of beef steers fed alfalfa hay or a high concentrate diet. Can. J. Anim. Sci. 69:215-223.

Kennedy, P. M. 1980. The effects of dietary sucrose and the concentrations of plasma urea and rumen ammonia on the degradation of urea in the gastrointestinal tract of cattle. Br. J. Nutr. 43:125-140.

Kennedy, P. M., R. T. J. Clarke, and L. P. Milligan. 1981. Influences of dietary sucrose and urea on transfer of endogenous urea to the rumen of sheep and numbers of epithelial bacteria. Br. J. Nutr. 46:533-541.

Khorasani, G. R., E. K. Okine, and J. J. Kennelly. 1996. Forage source alters nutrient supply to the intestine without influencing milk yield. J. Dairy Sci. 79:862-872.

Khorvash, M., S. Kargar, G. R. Ghorbani, A. Ghaempour, M. Boroumand-Jazi, and W. Z. Yang. 2014. Lactational performance, nutrient digestibility and fermentation characteristics of Holstein dairy cows in response to feeding wheat factory sewage. J. Appl. Anim. Res. 42:465-473.

Kim, K. H., J. J. Choung, and D. G. Chamberlain. 1999. Effects of varying the degree of synchrony of energy and nitrogen release in the rumen on the synthesis of microbial protein in lactating dairy cows consuming a diet of grass silage and a cereal-based concentrate. J. Sci. Food Agric. 79:1441-1447.

Kristensen, N. B. 2005. Splanchnic metabolism of volatile fatty acids in the dairy cow. Anim. Sci. 80:3-10.

Lapierre, H., J. F. Bernier, P. Dubreuil, C. K. Reynolds, C. Farmer, D. R. Ouellet, and G. E. Lobley. 2000. The effect of feed intake level on splanchnic metabolism in growing beef steers. J. Anim. Sci. 78:1084-1099.

Lapierre, H., and G. E. Lobley. 2001. Nitrogen recycling in the ruminant: A review. J. Dairy Sci. 84(E-Suppl.):E223-E236.

Lapierre, H., D. R. Ouellet, R. Berthiaume, R. Martineau, G. Holtrop, and G. E. Lobley. 2008. Distribution of ${ }^{15} \mathrm{~N}$ in amino acids during ${ }^{15} \mathrm{~N}$-leucine infusion: Impact on the estimation of endogenous flows in dairy cows. J. Dairy Sci. 91:2702-2714. 
Lobley, G. E., D. M. Bremner, and G. Zuur. 2000. Effects of diet quality on urea fates in sheep as assessed by refined, non-invasive $\left.{ }^{15} \mathrm{~N}^{15} \mathrm{~N}\right]$-urea kinetics. Br. J. Nutr. 84:459-468.

Lu, Z., F. Stumpff, C. Deiner, J. Rosendahl, H. Braun, K. Abdoun, J. R. Aschenbach, and H. Martens. 2014. Modulation of sheep ruminal urea transport by ammonia and pH. Am. J. Physiol. Regul. Integr. Comp. Physiol. 307:R558-R570.

Marini, J. C., J. D. Klein, J. M. Sands, and M. E. V. Amburgh. 2004. Effect of nitrogen intake on nitrogen recycling and urea transporter abundance in lambs. J. Anim. Sci. 82:1157-1164.

Marini, J. C., and M. E. Van Amburgh. 2003. Nitrogen metabolism and recycling in Holstein heifers. J. Anim. Sci. 81:545-552.

McCleary, B. V., T. S. Gibson, and D. C. Mugford. 1997. Measurement of total starch in cereal products by amyloglucosidase-alphaamylase method: collaborative study. J. AOAC Int. 80:571-579.

NRC. 2001. Nutrient Requirements of Dairy Cattle. 7th rev. ed. Natl. Acad. Press, Washington, DC.

Oba, M. 2011. Review: Effects of feeding sugars on productivity of lactating dairy cows. Can. J. Anim. Sci. 91:37-46.

Oba, M., and M. S. Allen. 1999. Evaluation of the importance of the digestibility of neutral detergent fiber from forage: effects on dry matter intake and milk yield of dairy cows. J. Dairy Sci. 82:589 596.

Ouellet, D. R., R. Berthiaume, G. Holtrop, G. E. Lobley, R. Martineau, and H. Lapierre. 2010. Effect of method of conservation of timothy on endogenous nitrogen flows in lactating dairy cows. J. Dairy Sci. 93:4252-4261.

Ouellet, D. R., M. Demers, G. Zuur, G. E. Lobley, J. R. Seoane, J. V. Nolan, and H. Lapierre. 2002. Effect of dietary fiber on endogenous nitrogen flows in lactating dairy cows. J. Dairy Sci. 85:3013-3025.

Penner, G. B., L. L. Guan, and M. Oba. 2009. Effects of feeding Fermenten on ruminal fermentation in lactating Holstein cows fed two dietary sugar concentrations. J. Dairy Sci. 92:1725-1733.

Penner, G. B., and M. Oba. 2009. Increasing dietary sugar concentration may improve dry matter intake, ruminal fermentation, and productivity of dairy cows in the postpartum phase of the transition period. J. Dairy Sci. 92:3341-3353.

Piwonka, E. J., J. L. Firkins, and B. L. Hull. 1994. Digestion in the rumen and total tract of forage-based diets with starch or dextrose supplements fed to Holstein heifers. J. Dairy Sci. 77:1570-1579.

Preiss, J., and T. Romeo. 1989. Physiology, biochemistry and genetics of bacterial glycogen synthesis. Adv. Microb. Physiol. 30:183-238.

Reynal, S. M., and G. A. Broderick. 2005. Effect of dietary level of rumen-degraded protein on production and nitrogen metabolism in lactating dairy cows. J. Dairy Sci. 88:4045-4064.

Reynal, S. M., G. A. Broderick, and C. Bearzi. 2005. Comparison of four markers for quantifying microbial protein flow from the rumen of lactating dairy cows. J. Dairy Sci. 88:4065-4082.

Reynal, S. M., I. R. Ipharraguerre, M. Liñeiro, A. F. Brito, G. A. Broderick, and J. H. Clark. 2007. Omasal flow of soluble proteins, peptides, and free amino acids in dairy cows fed diets supplemented with proteins of varying ruminal degradabilities. J. Dairy Sci. 90:1887-1903.

Reynolds, C. K., D. L. Harmon, R. L. Prior, and H. F. Tyrrell. 1994. Effects of mesenteric vein L-alanine infusion on liver metabolism of organic acids by beef heifers fed diets differing in forage: concentrate ratio. J. Anim. Sci. 72:3196-3206.

Reynolds, C. K., and G. B. Huntington. 1988. Partition of portaldrained visceral net flux in beef steers. Br. J. Nutr. 60:539-551.

Roseler, D. K., J. D. Ferguson, C. J. Sniffen, and J. Herrema. 1993. Dietary protein degradability effects on plasma and milk urea nitrogen and milk nonprotein nitrogen in Holstein cows. J. Dairy Sci. 76:525-534.

Russell, J. B., J. D. O'Connor, D. G. Fox, P. J. Van Soest, and C. J. Sniffen. 1992. A net carbohydrate and protein system for evaluating cattle diets: I. Ruminal fermentation. J. Anim. Sci. 70:35513561

Sannes, R. A., M. A. Messman, and D. B. Vagnoni. 2002. Form of rumen-degradable carbohydrate and nitrogen on microbial protein synthesis and protein efficiency of dairy cows. J. Dairy Sci. 85:900-908.

Siddons, R. C., J. Paradine, D. E. Beever, and P. R. Cornell. 1985. Ytterbium acetate as a particulate-phase digesta-flow marker. Br. J. Nutr. 54:509-519.

Slater, A. L., M. L. Eastridge, J. L. Firkins, and L. J. Bidinger. 2000. Effects of starch source and level of forage neutral detergent fiber on performance of dairy cows. J. Dairy Sci. 83:313-321.

Spanghero, M., and Z. M. Kowalski. 1997. Critical analysis of N balance experiments with lactating cows. Livest. Prod. Sci. 52:113122.

Stewart, G. S., and C. P. Smith. 2005. Urea nitrogen salvage mechanisms and their relevance to ruminants, non-ruminants and man Nutr. Res. Rev. 18:49-62.

Theurer, C. B., G. B. Huntington, J. T. Huber, R. S. Swingle, and J. A. Moore. 2002. Net absorption and utilization of nitrogenous compounds across ruminal, intestinal, and hepatic tissues of growing beef steers fed dry-rolled or steam-flaked sorghum grain. J. Anim. Sci. 80:525-532.

Udén, P., P. E. Colucci, and P. J. Van Soest. 1980. Investigation of chromium, cerium and cobalt as markers in digesta. Rate of passage studies. J. Sci. Food Agric. 31:625-632.

Van Amburgh, M. E., E. A. Collao-Saenz, R. J. Higgs, D. A. Ross, E. B. Recktenwald, E. Raffrenato, L. E. Chase, T. R. Overton, J. K. Mills, and A. Foskolos. 2015. The Cornell Net Carbohydrate and Protein System: Updates to the model and evaluation of version 6.5. J. Dairy Sci. 98:6361-6380.

Van Soest, P. J., J. B. Robertson, and B. A. Lewis. 1991. Methods for dietary fiber, neutral detergent fiber, and nonstarch polysaccharides in relation to animal nutrition. J. Dairy Sci. 74:3583-3597.

Vicente, F., A. Sarraseca, A. de Vega, and J. A. Guada. 2004. Performance of several $\mathrm{Cr}$ and $\mathrm{Yb}$ analytical techniques applied to samples of different biological origin (digesta or faeces). J. Sci. Food Agric. 84:2035-2040.

Wickersham, T. A., E. C. Titgemeyer, R. C. Cochran, and E. E. Wickersham. 2009. Effect of undegradable intake protein supplementation on urea kinetics and microbial use of recycled urea in steers consuming low-quality forage. Br. J. Nutr. 101:225-232. 